\title{
Challenges of Achieving 2012 IECC Air Sealing Requirements in Multifamily Dwellings
}

S. Klocke, O. Faakye, and S. Puttagunta Consortium for Advanced Residential Buildings

October 2014 


\begin{abstract}
NOTICE
This report was prepared as an account of work sponsored by an agency of the United States government. Neither the United States government nor any agency thereof, nor any of their employees, subcontractors, or affiliated partners makes any warranty, express or implied, or assumes any legal liability or responsibility for the accuracy, completeness, or usefulness of any information, apparatus, product, or process disclosed, or represents that its use would not infringe privately owned rights. Reference herein to any specific commercial product, process, or service by trade name, trademark, manufacturer, or otherwise does not necessarily constitute or imply its endorsement, recommendation, or favoring by the United States government or any agency thereof. The views and opinions of authors expressed herein do not necessarily state or reflect those of the United States government or any agency thereof.
\end{abstract}

Available electronically at http://www.osti.gov/scitech

Available for a processing fee to U.S. Department of Energy and its contractors, in paper, from:

U.S. Department of Energy

Office of Scientific and Technical Information

P.O. Box 62

Oak Ridge, TN 37831-0062

phone: 865.576 .8401

fax: 865.576 .5728

email: mailto:reports@adonis.osti.gov

Available for sale to the public, in paper, from:

U.S. Department of Commerce

National Technical Information Service

5285 Port Royal Road

Springfield, VA 22161

phone: 800.553.6847

fax: 703.605.6900

email: orders@ntis.fedworld.gov 


\title{
Challenges of Achieving 2012 IECC Air Sealing Requirements in Multifamily Dwellings
}

\author{
Prepared for: \\ The National Renewable Energy Laboratory \\ On behalf of the U.S. Department of Energy's Building America Program \\ Office of Energy Efficiency and Renewable Energy \\ 15013 Denver West Parkway \\ Golden, CO 80401 \\ NREL Contract No. DE-AC36-08GO28308 \\ Prepared by: \\ Steve Klocke, Omari Faakye, and Srikanth Puttagunta \\ Steven Winter Associates, Inc. \\ of the \\ Consortium for Advanced Residential Buildings (CARB) \\ 61 Washington Street \\ Norwalk, CT 06854 \\ NREL Technical Monitor: Stacey Rothgeb \\ Prepared under Subcontract No. KNDJ-0-40342-04
}

October 2014 
The work presented in this report does not represent performance of any product relative to regulated minimum efficiency requirements.

The laboratory and/or field sites used for this work are not certified rating test facilities. The conditions and methods under which products were characterized for this work differ from standard rating conditions, as described.

Because the methods and conditions differ, the reported results are not comparable to rated product performance and should only be used to estimate performance under the measured conditions. 


\section{Contents}

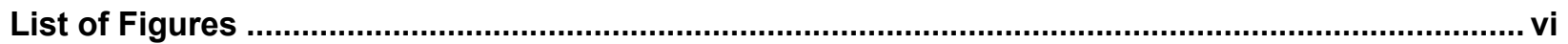

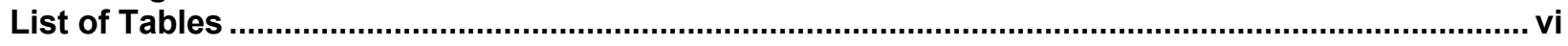

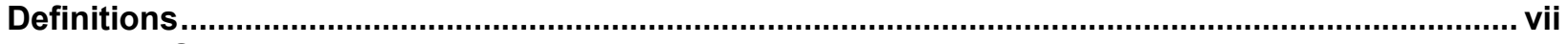

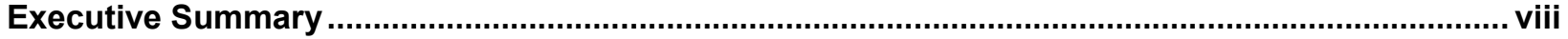

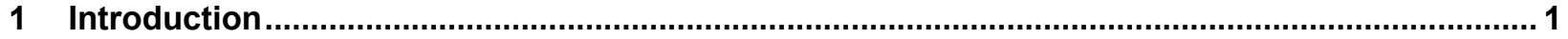

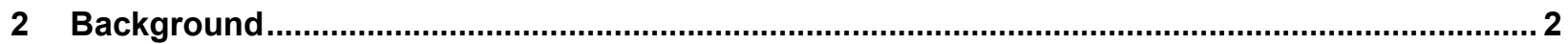

2.1 What Makes Multifamily Enclosures Different From Single-Family Enclosures?............2

2.2 How Much Air Leaks Through Exterior Surfaces Versus Adiabatic Surfaces?.................3

2.3 What Reference Resources Are Currently Available That Discuss Strategies for Reducing

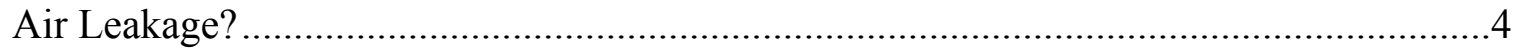

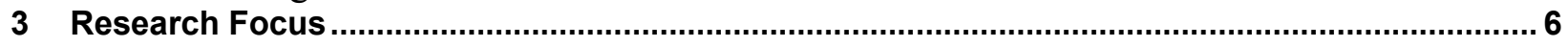

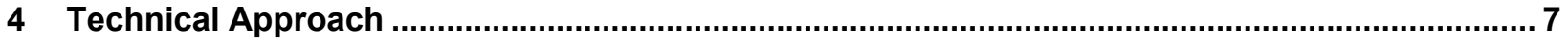

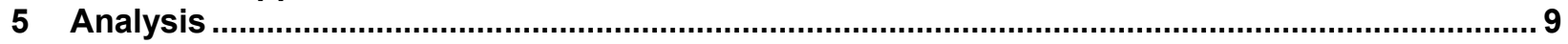

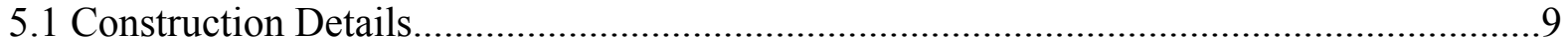

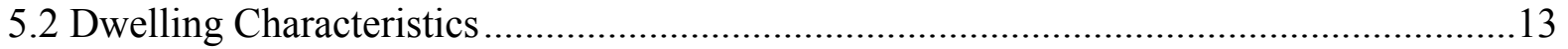

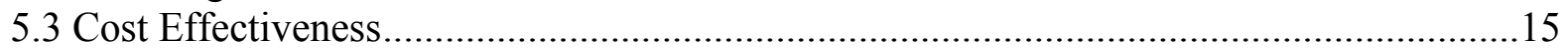

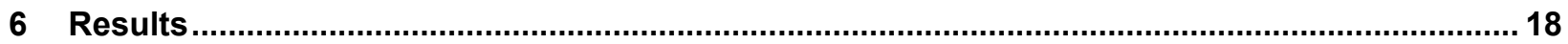

6.1 How Achievable Is the 2012 IECC Climate Zone 3-8 Infiltration Value of $3 \mathrm{ACH}_{50}$ in Multifamily Dwellings When Accounting for Unguarded Blower Door Testing? ...........18

6.2 What Insulation/Air Sealing Strategies Help Buildings Achieve the 2012 IECC Air Leakage Requirement?

6.3 What Lessons Can Be Learned From the Air Sealing/Insulating Techniques Employed in

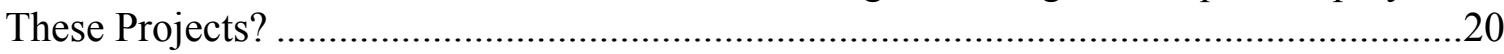

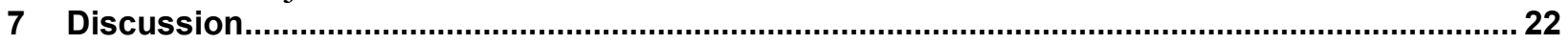

7.1 What Other Techniques Could Have Been Used To Reduce Air Leakage?.....................22

7.2 To Meet the 2012 IECC Air Leakage Requirement, Should Builders Spend Money on Air Sealing or Guarded Testing?.

7.3 Should the IECC Air Leakage Requirement Be Based on Enclosure Area Rather Than Volume?

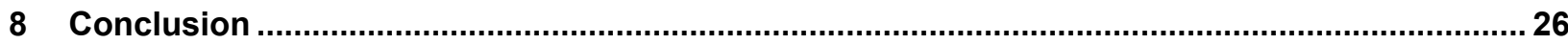

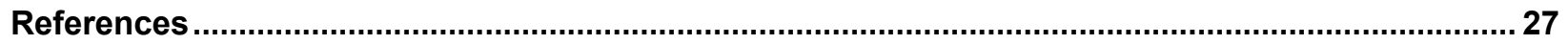

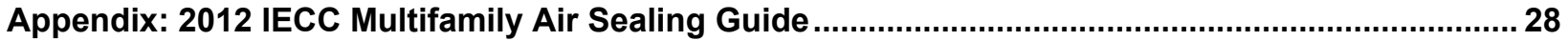




\section{List of Figures}

Figure 1. Detached versus attached dwelling enclosures............................................................. 2

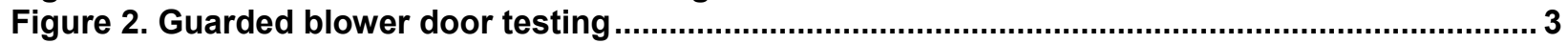

Figure 3. Airtightness results of 600+ green apartments (green denotes apartments that achieved $<0.25 \mathrm{cfm} 50 / \mathrm{ft}^{2}$ of enclosure area, while red denotes apartments that exceeded this goal) ....... 5

Figure 4. The three low-rise multifamily projects that were evaluated: CV (left), SH (top right), and HV (bottom right)

Figure 5. Framing plans at HV were well implemented by framers and set up the air sealing crew for success.

or wall air sealing and insulation used at $\mathrm{CV}$ and $\mathrm{SH}$

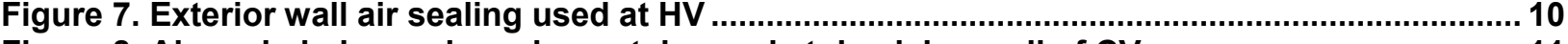

Figure 8. Air sealed plywood smoke curtain used at demising wall of CV ...................................... 11

Figure 9. Air sealed sheetrock smoke curtain used at demising wall of $\mathrm{SH}$................................. 11

Figure 10. Air sealed structural framing used at demising wall of HV ........................................... 12

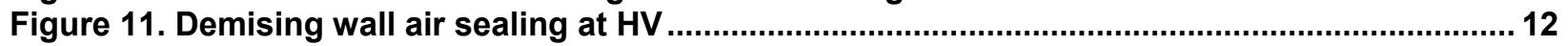

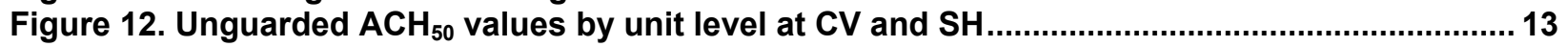

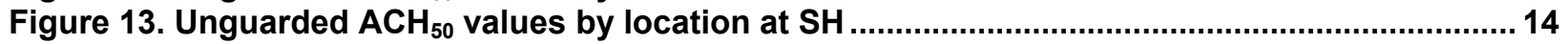

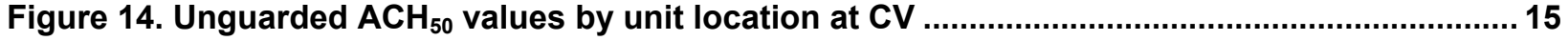

Figure 15. Annualized energy-related cost at decreasing $\mathrm{ACH}_{50}$ values ..................................... 17

Figure 16. ACH values from both unguarded and estimated guarded testing .................................. 18

Figure 17. Unguarded $\mathrm{CFM}_{50} / \mathrm{ft}^{2}$ of enclosure area ................................................................... 19

Figure 18. Air sealing detail-seal drywall to framing at wall intersections.......................................22

Figure 19. Air sealing detail-seal top of double-framed walls.................................................... 22

Figure 20. Air sealing detail-separate framing cavities with drywall .......................................... 23

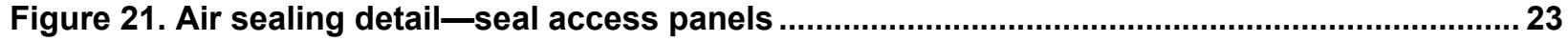

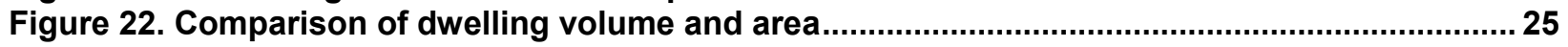

Unless otherwise noted, all figures were created by CARB.

\section{List of Tables}

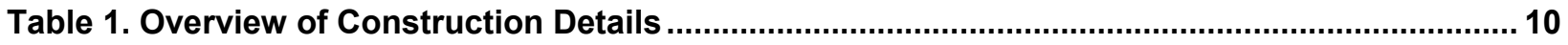

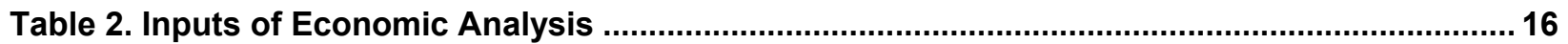

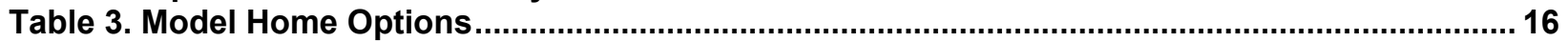

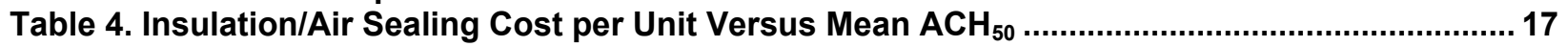

Unless otherwise noted, all tables were created by CARB. 


\section{Definitions}

$\mathrm{ACH}$

$\mathrm{ACH} 50$

AERC

CARB

$\operatorname{ccSPF}$

$\mathrm{CV}$

HV

IECC ocSPF

$\mathrm{SH}$

SWA
Air Changes per Hour

Air Changes per Hour at 50 Pascal

Annualized Energy-Related Cost

Consortium for Advanced Residential Buildings

Closed Cell Spray Polyurethane Foam

Coburg Village

Housing Visions

International Energy Conservation Code

Open Cell Spray Polyurethane Foam

Sharker 4

Steven Winter Associates 


\section{Executive Summary}

While previous versions of the International Energy Conservation Code (IECC) have included provisions to improve the airtightness of dwellings, for the first time, the 2012 IECC mandates compliance verification through blower door testing. Simply completing the Air Barrier and Insulation Installation Checklist through visual inspection is no longer sufficient by itself. In addition, the 2012 IECC mandates a significantly stricter air sealing requirement. In climate zones 3-8, air leakage may not exceed $3 \mathrm{ACH}_{50}$, which is a significant reduction from the 2009 IECC requirement of $7 \mathrm{ACH}_{50}$. This requirement is for all residential buildings, which includes detached one- and two-family dwellings and multiple single-family dwellings (townhouses) as well as Group R-2 (apartment dwellings), R-3, and R-4 buildings three stories or less in height above-grade plane. While this air leakage rate requirement is an important component to achieving an efficient building thermal envelope, currently, the code language doesn't explicitly address differences between single-family and multifamily applications.

In addition, the 2012 IECC does not explicitly provide an option to sample dwellings for larger multifamily buildings, so compliance would have to be verified on every unit. According to Sydney Roberts, program manager at Southface Home Services, "The size and complexity of a multifamily building makes it challenging to measure air leakage between individually occupied units, and between a unit and the outside."

Given the 2012 IECC air leakage requirements on the horizon, several of the Consortium for Advanced Residential Buildings' (CARB) multifamily builder partners are evaluating how best to comply with the 2012 IECC air leakage requirements. Builders are not sure whether it is more practical or beneficial to simply pay for guarded testing or to revise their air sealing strategies to improve compartmentalization to comply with code requirements based on unguarded blower door testing.

CARB conducted research to assess the feasibility of meeting the 2012 IECC air leakage requirements with unguarded blower door testing. By analyzing testing results from numerous dwellings within three multifamily projects, CARB compared performance based on several variables, including construction details (insulation, framing, etc.) and design characteristics (dwelling layout, location within the building, etc.). Additional analysis was performed to explore the cost effectiveness of various air sealing techniques.

Based on these findings, CARB created an air sealing guideline in low rise, wood construction multifamily buildings. This guide will provide builders/developers/contractors the critical details needed to comply with the air leakage requirements of the 2012 IECC. Still, achieving an unguarded $3 \mathrm{ACH}_{50}$ in multifamily dwellings is not easy. In addition to applying the strategies detailed in the air sealing guide provided in the Appendix, the following items were determined to be critical for compliance with the 2012 IECC air leakage requirement in multifamily dwellings:

- Reducing air leakage starts during the design development process; design teams must make decisions that allow for the air leakage requirement to be met. 
- Construction teams must understand the design teams' intent while incorporating their experiences from previous successes and failures. Implementation is crucial; subcontractors will not meet their air leakage reduction goals without heightened awareness, support and oversight.

- Until design and construction teams become familiar and comfortable with the tasks required to meet the air leakage requirement, construction schedules will be slowed down and implementation costs will be high.

While CARB believes the goals of the 2012 IECC air leakage requirement are desirable, there is concern that this requirement is geared toward single-family construction only and doesn't address the nuances of multifamily construction. Rather than quantifying air leakage based on a dwelling's volume, one might argue that air leakage should be quantified based on how much of a dwelling's enclosure area is exposed to ambient conditions. This idea has implications for both attached and detached dwellings. In any dwelling, energy loss occurs at the exterior enclosure, and the relationship between the dwelling's enclosure and its volume is not constant. For example, a dwelling with an elongated plan will have a larger enclosure area than a squareshaped dwelling of the same floor area. The discrepancy in exterior enclosure area is even greater when comparing attached and detached dwellings. CARB believes that an exception for testing multifamily buildings (a building containing multiple dwelling units) based on a metric of cubic feet per minute per square foot of enclosure area (all six sides of the dwelling unit) would be beneficial to the construction industry while maintaining the goal/intent of the code requirement. In addition, a methodology for test sampling is needed. 


\section{Introduction}

While previous versions of the International Energy Conservation Code (IECC) have included provisions to improve the airtightness of dwellings, for the first time, the 2012 IECC mandates compliance verification through blower door testing. Simply completing the Air Barrier and Insulation Installation Checklist through visual inspection is no longer sufficient by itself. In addition, the 2012 IECC mandates a significantly stricter air sealing requirement. In climate zones 3-8, air leakage may not exceed $3 \mathrm{ACH}_{50}$, which is a significant reduction from the 2009 IECC requirement of $7 \mathrm{ACH}_{50} . \mathrm{ACH}_{50}$ refers to the air changes per hour when testing is conducted with a blower door at a pressure of 0.2 in. w.g. (50 Pascal). This requirement is for all residential buildings, which includes detached one- and two-family dwellings and multiple single-family dwellings (townhouses) as well as Group R-2 (apartment dwellings), R-3, and R-4 buildings three stories or less in height above grade plane. While this air leakage rate requirement is an intrinsic component to achieving an efficient building thermal envelope, currently, the code language doesn't explicitly address differences between single-family and multifamily applications (IECC 2009, 2012).

The air leakage requirements were established for single-family detached homes. The intent of the blower door test is to determine the amount of air leakage to outdoors, as this would be associated with an energy penalty. In attached housing, some of the air leakage will be to neighboring units. To achieve an equivalent metric in attached housing, a guarded blower door test needs to be performed. Unfortunately, there is no standard test method similar to the ASTM E1827 and E779 ("Standard Test Methods for Determining Air Tightness/Leakage in Detached Units") that can be readily applied to attached housing. The Energy Conservatory and Camroden Associates released a Blower Door Application Guide: Beyond Single Family Residential (Brennan et al. 2014) that provides guidance on multifamily buildings and large facilities, but the focus was primarily for whole-building infiltration testing.

In addition, the 2012 IECC does not provide an option to sample dwellings for larger multifamily buildings, so compliance would have to be verified on every unit. According to Sydney Roberts, program manager at Southface Home Services, "The size and complexity of a multifamily building makes it challenging to measure air leakage between individually occupied units, and between a unit and the outside." 1 Therefore, several multifamily builder partners of the Consortium for Advanced Residential Buildings (CARB), a Building America research team led by Steven Winter Associates, Inc. (SWA), requested assistance with evaluating how to comply with the 2012 IECC air leakage requirements if adopted by their state code. As testing fees and construction costs vary widely, the builders were not sure whether it would be more practical/beneficial to simply pay for guarded testing or to revise their air sealing strategies to improve compartmentalization to comply with code requirements based on unguarded blower door testing. As 2012 IECC air leakage rates weren't mandatory for these projects, these field demonstrations were used more as learning labs for the builders and their contractors to see the performance of the current construction specifications and what additional changes may be needed for future projects.

\footnotetext{
${ }^{1}$ http://www.southface.org/sfjournal/summer_2012/files/assets/seo/page11.html
} 


\section{Background}

Before trying to determine how to meet the IECC air leakage requirement in multifamily buildings, it is important to understand the unique characteristics of multifamily construction.

\subsection{What Makes Multifamily Enclosures Different From Single-Family Enclosures?}

Detached dwellings are enclosed primarily by exterior surfaces, whereas the enclosure of attached dwellings incorporates interior surfaces (Figure 1). These interior surfaces are typically dealt with as adiabatic surfaces. Heat is not transferred through adiabatic surfaces because the spaces on both sides of the surface are conditioned to a comparable degree; examples of adiabatic surfaces include demising walls between units, corridor walls, ceilings/floors above/below other units or non-unit areas, and other surfaces between two conditioned areas.

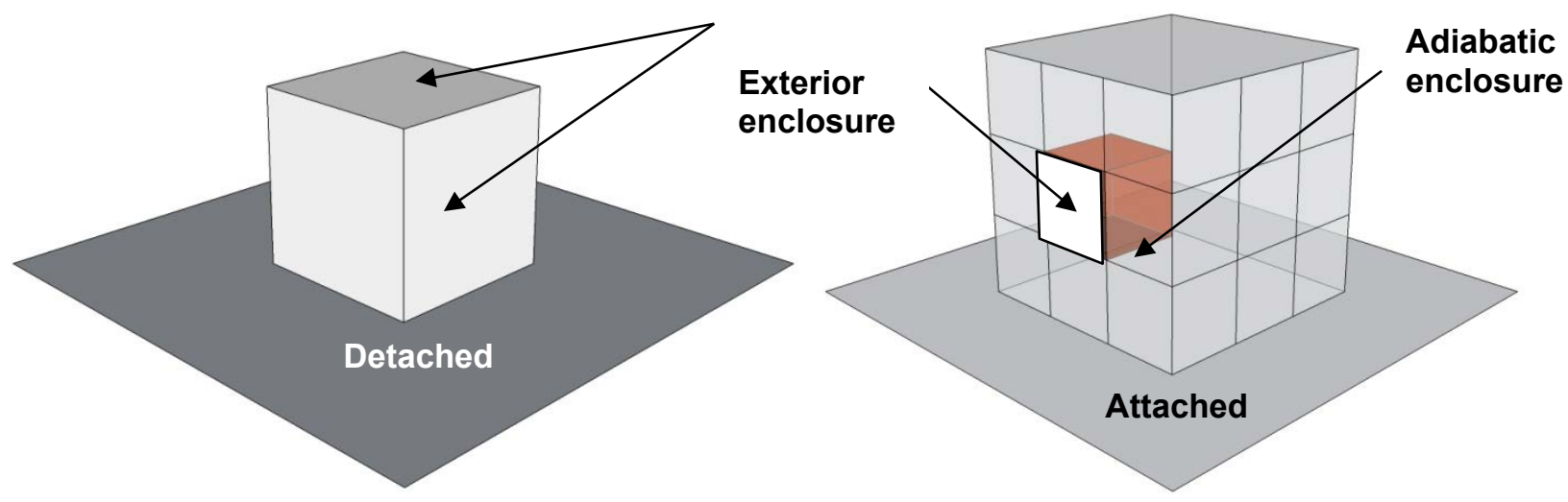

Figure 1. Detached versus attached dwelling enclosures

In multifamily construction, adiabatic surfaces are usually treated differently than exterior surfaces. Air leakage at the adiabatic surfaces in an attached dwelling tends to have minimal impact on energy performance when analyzing an individual dwelling unit because the air in the adjacent spaces is assumed to be at nearly the same temperature and therefore, does not require additional conditioning. Still, there is the potential for an interior surface to be connected to the exterior conditions through indirect pathways. In addition, permanent seals are needed at all large exterior openings of chases and framing edges to roof/wall joints, to floor/wall joints, party wall edges, rooftop mechanical openings, crawlspaces, mechanical rooms, loading docks and garages. These interior bypasses, along with bypasses directly to outdoors, increase overall building air leakage due to stack effect acting over a larger height (Lstiburek 2005). Yet, for design and modeling purposes, these interior walls are generally treated as adiabatic.

Most builders are familiar with the various strategies for reducing air leakage at exterior assemblies, whereas the typical scope of work at adiabatic surfaces focuses on fire-stopping and acoustic insulation for sound attenuation. Reducing interior air leakage in an attached dwelling is referred to as compartmentalization. 


\subsection{How Much Air Leaks Through Exterior Surfaces Versus Adiabatic Surfaces?}

The standard method for testing air leakage includes one set of equipment, a blower door (or duct blaster for small units), set up in the entry door of dwelling being tested. The blower door depressurizes or pressurizes the unit to a given pressure differential and the rate at which air is being drawn out of or into the dwelling is recorded. $A \pm 50$ Pascal pressure differential is the standard testing criteria to allow for universal comparison of air leakage in buildings between verifiers; it does not represent actual air leakage under natural operating conditions.

In attached dwellings, an alternative method for testing air leakage, called "guarded" testing, includes additional blower doors being set up in the conditioned spaces adjacent to the unit being tested (can alternatively be done by using a fan or multiple fans to pressure the rest of the floor or building). The additional blower doors are adjusted to neutralize the pressure differential between the adjoining surfaces to the main unit being evaluated, resulting in a leakage value that can be attributed primarily to air movement at the exterior surfaces, thus impacting energy performance. A preliminary finding of a 2006 study by Lawrence Berkeley National Laboratory found that multifamily dwellings are 1.5-2 times as leaky per unit surface area as single-family detached homes (Gadgil et al. 2006).

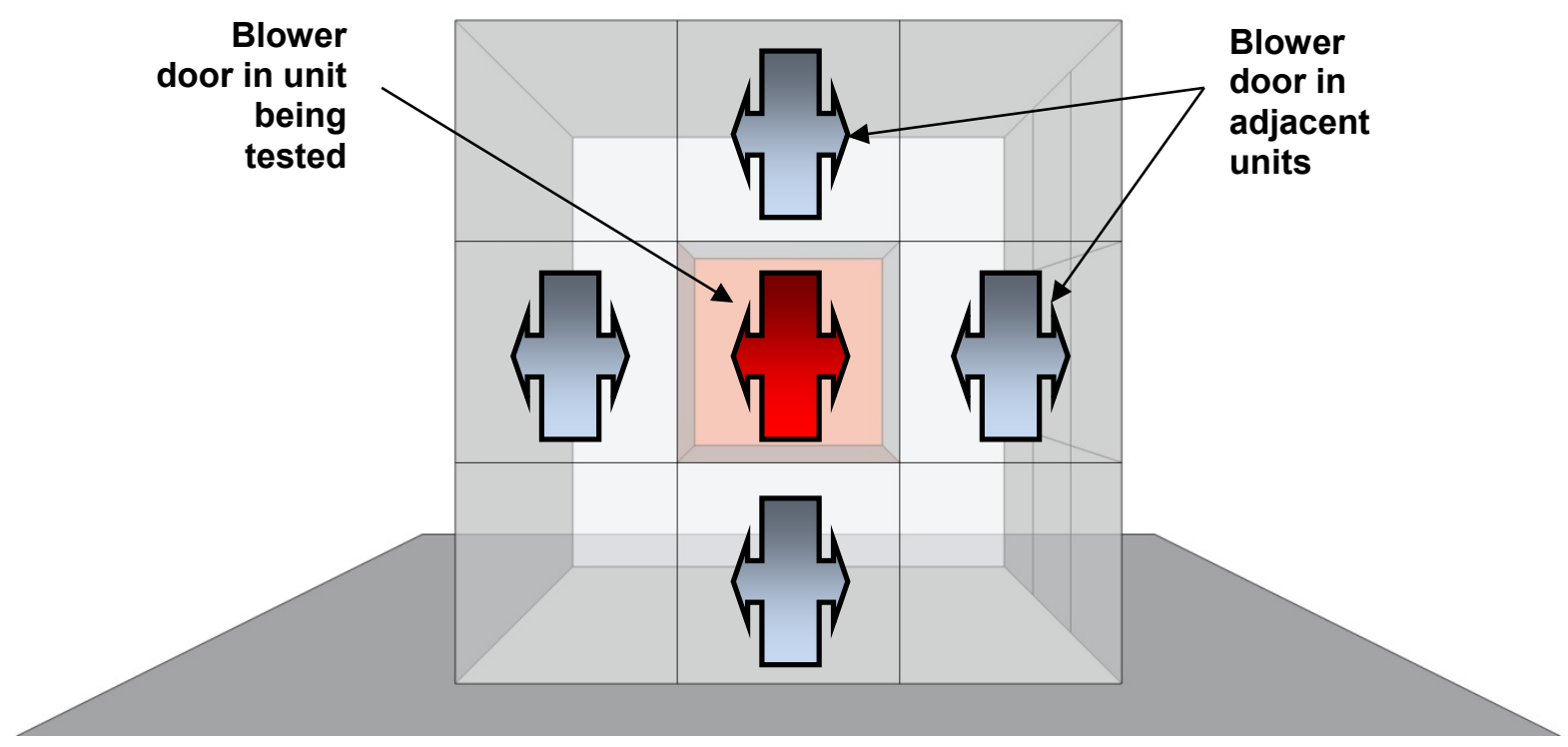

Figure 2. Guarded blower door testing

A handful of other studies have been performed to compare guarded and unguarded testing results. The New River Center for Energy Research \& Training presented a study in 2012 that showed a $22 \%$ reduction when changing from unguarded to guarded air leakage testing. ${ }^{2}$ Similarly, the Center for Energy and Environment presented findings in 2012 that showed that $27 \%$ of air leakage was occurring at demising walls. ${ }^{3}$ Using blower door test data available from numerous multifamily projects, CARB has also developed a framework for a simple algorithm

\footnotetext{
${ }^{2}$ http://www.energyoutwest.org/eow library/_ past confs/EOW 2012 Presentations/ Air\%20Tightness\%20Testing\%20of\%20Multifamily\%20Buildings\%20-\%20Anthony\%20Cox.pdf

${ }^{3}$ http://www.slideshare.net/mnceeInEx/mf-sealing-and-ventilation-bb-il-2012-v5-dlb
} 
based on unguarded blower door tests and a few basic dwelling unit characteristics (Faakye et al. 2013). Results for the new construction multifamily apartments in that dataset suggest an average air leakage reduction of $\sim 30 \%$ with guarded blower door testing.

\subsection{What Reference Resources Are Currently Available That Discuss Strategies for Reducing Air Leakage?}

The U.S. Department of Energy's Building Energy Codes Program has published the "Air Leakage Guide: Meeting the Air Leakage Requirements of the 2012 IECC" (BECP 2011). This guide primarily discusses the details of Table R402.4.1.1 Air Barrier and Insulation Installation Checklist of the 2012 IECC. These specifications were developed and vetted through the U.S. Department of Energy's Building America program and have become a key component of the U.S. Environmental Protection Agency's ENERGY STAR ${ }^{\circledR}$ Certified New Homes Program (through the Thermal Enclosure System Rater Checklist). This resource is geared toward singlefamily dwellings and generally does not address the issues of air sealing and testing multifamily dwelling units.

There are several Building America resources that address multifamily air sealing. In 2012, CARB completed a measure guideline on air sealing attics and roof assemblies in multifamily buildings (Otis and Maxwell 2012). This guideline explains why air sealing is desirable, explores related health and safety issues, and identifies common air leakage points in multifamily building attics. In addition, it also gives an overview of materials and techniques typically used to perform air sealing work. While a useful resource, it is geared more to existing building applications.

Another Building America team, Advanced Residential Integrated Energy Solutions, provides air sealing instructions in Appendix E of its technical report, Air Leakage Testing and Air Sealing in Existing Multifamily Units (Dentz and Conlin 2012). A key finding of this study was that sealing air pathways in the attic and basement, and not just individual dwellings, can affect air leakage in many units. Still this was again more focused on existing multifamily buildings.

The Building America Solution Center does have some new construction guidance, but this content focuses on air sealing multifamily party walls, ${ }^{4}$ which is geared more toward compartmentalization air sealing. This guidance was provided to specifically address sealing multifamily party walls, which is not address within the 2012 IECC Table R402.4.1.1 Air Barrier and Insulation Installation Checklist.

Using lessons learned on numerous past multifamily projects, SWA has developed air sealing guides specific to several multifamily construction types (wood, ${ }^{5}$ masonry, ${ }^{6}$ and garden style ${ }^{7}$ ) that include details specifically geared toward compartmentalization. SWA's builder partners have successfully used these guides to assemble comprehensive, cost-effective air sealing packages to achieve their air leakage reduction goals of less than $0.25 \mathrm{cfm}_{50} / \mathrm{ft}^{2}$ of enclosure area (Figure 3), which roughly equates to $4.5-5.5 \mathrm{ACH}_{50}$ for typical size apartment dwellings.

\footnotetext{
${ }^{4}$ https://basc.pnnl.gov/resource-guides/multifamily-party-walls\#block-views-guide-static-blocks-block-1

5 http://carb-swa.com/Collateral/Documents/CARB-SWA/Details/SWA-MultifamilyAirSealingGuide-Wood.pdf

6 http://carb-swa.com/Collateral/Documents/CARB-SWA/Details/SWA-MultifamilyAirSealingGuide-Masonry.pdf

7 http://carb-swa.com/Collateral/Documents/CARB-

SWA/Details/Air\%20Sealing\%20Guide\%20Garden\%20Style\%20_Version1.pdf
} 


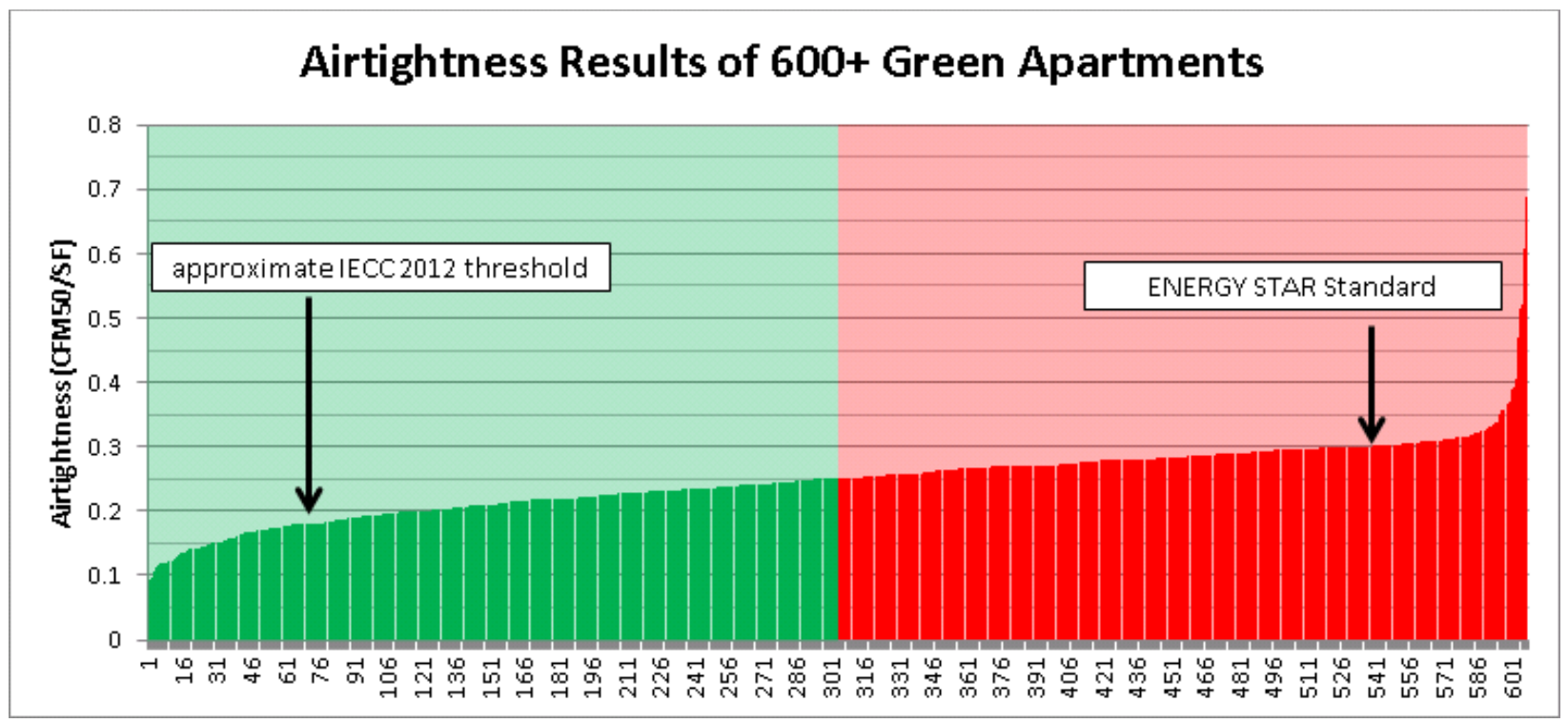

Figure 3. Airtightness results of $600+$ green apartments (green denotes apartments that achieved $<0.25 \mathrm{cfm} 50 / \mathrm{ft}^{2}$ of enclosure area, while red denotes apartments that exceeded this goal)

CARB and other researchers have found that $0.25 \mathrm{cfm}_{50} / \mathrm{ft}^{2}$ of enclosure area is a reasonable ratio that scales with all sizes of individual units and whole building enclosures. It is also consistent with the 2012 IECC commercial (four-story and taller buildings) air leakage ratio of 0.40 $\mathrm{cfm}_{75} / \mathrm{ft}^{2}$ of enclosure area. 


\section{Research Focus}

This project sought to create a well documented design and implementation strategy for air sealing in low-rise multifamily buildings which would assist in compliance with the building infiltration requirements of the 2012 IECC as it is adopted across the country, without having to go through the potential added expense of guarded blower door testing.

The following research questions were pursued:

- How achievable is the IECC climate zone 3-8 infiltration value of $3 \mathrm{ACH}_{50}$ in multifamily dwellings when accounting for unguarded blower door testing?

- What insulation and air sealing strategies help dwellings achieve the 2012 IECC $\mathrm{ACH}_{50}$ values with an unguarded blower door test?

- What lessons can be learned from the air sealing/insulating techniques employed in these projects? 


\section{Technical Approach}

CARB analyzed construction details and air leakage test results from three projects (Figure 4) in upstate New York, listed in order of final completion (all during 2013):

1. Coburg Village (CV): 78 units located in Rexford, New York (climate zone 5A)

2. Shaker 4 (SH): 69 units located in Watervliet, New York (climate zone 5A)

3. Housing Visions (HV): 50 units located in Syracuse, New York (climate zone 5A).

The same construction team was used at CV and SH; an entirely different construction team was used at HV. All projects achieved ENERGY STAR version 3 and LEED for Homes certification.
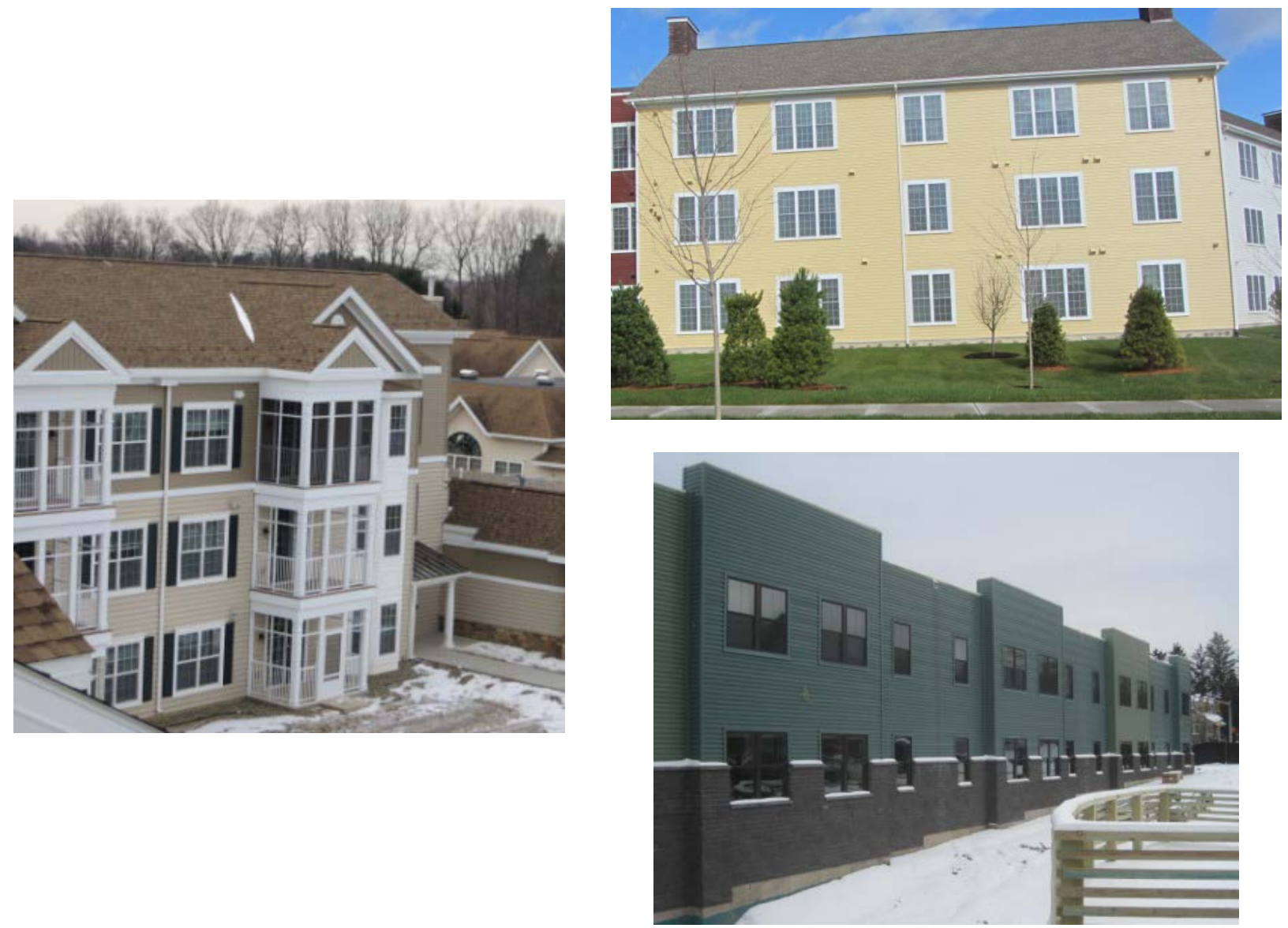

Figure 4. The three low-rise multifamily projects that were evaluated: CV (left), $\mathrm{SH}$ (top right), and HV (bottom right)

CARB performed unguarded blower door testing using the Residential Energy Network's sampling protocol in each of these buildings. The insulation and air sealing strategies were inspected and documented at the pre-drywall stage of construction and upon completion of construction. CARB also solicited feedback from the builders regarding challenges during construction and lessons learned after project completion. 


\section{Why unguarded blower door testing?}

Guarded blower door testing was previously performed on two units at the earlier Shaker 3 project by SWA. The staggered layout of these units resulted in a total of seven blower doors being needed to test a single unit (the unit of interest, two adjoining units on same floor, common hall, unit directly above, and the two units below due to staggered a layout). Equipment setup, coordination between verifiers, and coordination with building crew members took more than an hour per unit. When testing began, CARB found that the sequence in which the blower doors were ramped up had varying results, which could lead to a further divergence in test results between verifiers. This issue can be minimized through the use of computer software to bring all doors up to speed at the same rate.

In addition, the transport of pollutants, smoke/fire, and odors between apartments may have health and safety consequences, so there is an added benefit of achieving air leakage compliance through compartmentalization. Only focusing on sealing exterior air leakage without reducing the internal transport of air between dwelling units may exacerbate indoor air quality problems (Gadgil 2006). The builder wanted a more sound construction solution to ensure repeatable compliance with code air leakage requirements and enhanced living conditions. 


\section{Analysis}

CARB analyzed several factors that potentially affect air leakage as well as the cost effectiveness of air leakage reduction. The buildings were compared to each other in regard to differences in construction details, including framing, insulation and air sealing details, and the location of dwellings within each building was analyzed on a building-by-building basis. Cost effectiveness was evaluated using modeling software as well as data provided by the builders.

\subsection{Construction Details}

While CV and HV implemented site-built wood framing, HV utilized some advanced framing techniques and simplified floor plan configurations (one-bedroom units in an L-shaped plan versus two-bedroom units in a winding floor plan). HV framing plans were simplified by having ceiling joists running from corridor to exterior walls. Whether by design or implementation, the framing at $\mathrm{HV}$ was significantly neater with fewer framing members, which allowed connections between framing members to be tighter. This allowed for easier air sealing, rater inspections, and seems to have fostered pride for construction site cleanliness (Figure 5).

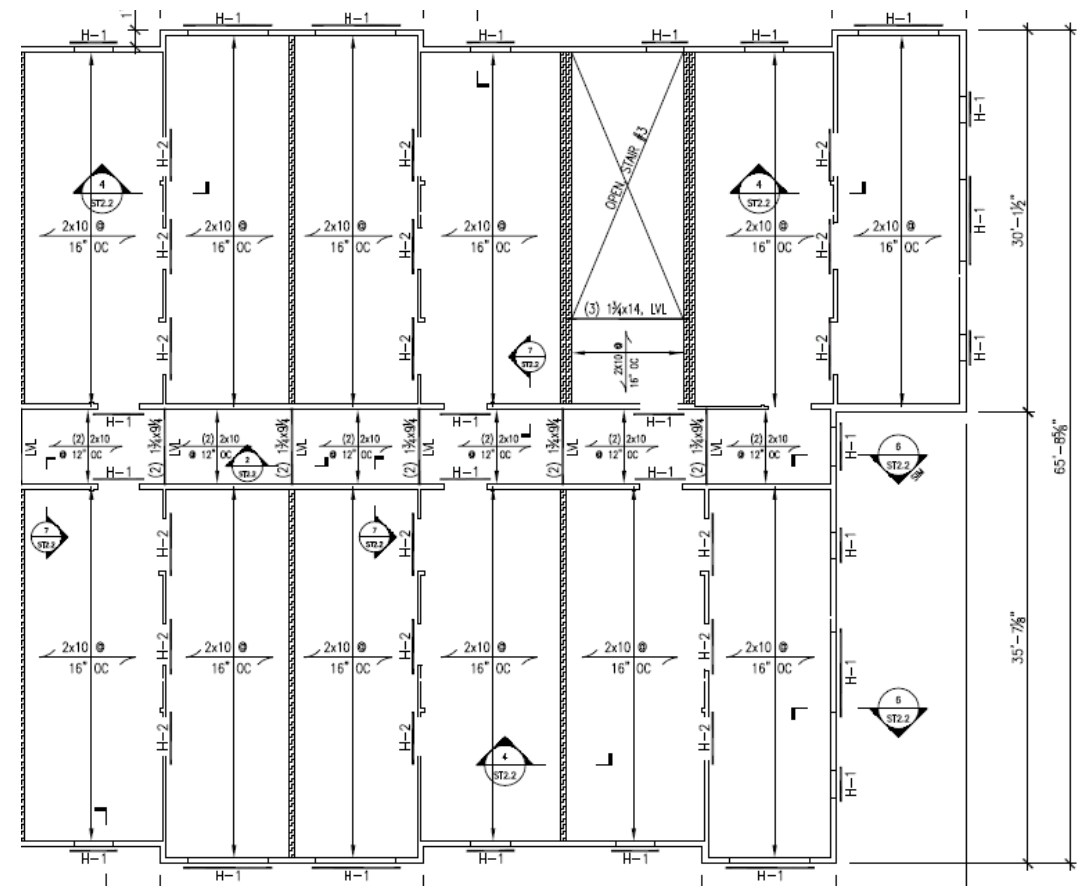

Figure 5. Framing plans at $\mathrm{HV}$ were well implemented by framers and set up the air sealing crew for success

(courtesy of Holmes King Kallquist \& Associates, LLP)

As shown in Table 1, the three projects utilized a variety of air sealing details at the exterior and adiabatic surfaces. Closed-cell spray polyurethane foam (ccSPF) insulation was initially used at the exterior walls at $\mathrm{CV}$, but the builder switched to elastomeric sealant and blown-in fiberglass batts due to fire-rated assembly requirements (Figure 6); discrepancies in air leakage and cost were negligible between these two specifications. This later specification was also used at SH. At $\mathrm{HV}$, ccSPF insulation was used on all exterior walls (Figure 7), which was allowed because this building was classified as a different construction type. 
Table 1. Overview of Construction Details

\begin{tabular}{|c|c|c|c|}
\hline Detail & $\mathrm{CV}$ & SH & HV \\
\hline Framing & $\begin{array}{l}\text { Site-built wood; } \\
\text { open-web floor trusses; } \\
\text { resilient channels at } \\
\text { demising and corridor } \\
\text { walls }\end{array}$ & $\begin{array}{l}\text { Panelized wood; } \\
\text { open-web floor trusses; } \\
\text { resilient channels at } \\
\text { corridor walls }\end{array}$ & $\begin{array}{l}\text { Site-built wood; } \\
\text { advanced framing } \\
\text { techniques; } \\
\text { solid wood floor } \\
\text { framing }\end{array}$ \\
\hline $\begin{array}{l}\text { Exterior } \\
\text { Insulation/Air } \\
\text { Sealing }\end{array}$ & $\begin{array}{l}\text { ccSPF (in } 2 \text { of } 9 \text { building } \\
\text { sections); elastomeric } \\
\text { sealant and blown-in } \\
\text { fiberglass (in remainder of } \\
\text { building) }\end{array}$ & $\begin{array}{l}\text { Elastomeric sealant and } \\
\text { blown-in fiberglass }\end{array}$ & ccSPF \\
\hline $\begin{array}{c}\text { Interior Air } \\
\text { Sealing } \\
\text { (at Demising/ } \\
\text { Corridor Walls) }\end{array}$ & $\begin{array}{l}\text { Fire-stopping; } \\
\text { acoustic sealant; } \\
\text { caulk at electrical boxes; } \\
\text { foam at pipe penetrations }\end{array}$ & $\begin{array}{l}\text { Fire-stopping; } \\
\text { acoustic sealant; } \\
\text { caulk at electrical boxes; } \\
\text { foam at pipe penetrations; } \\
\text { tape at ducts }\end{array}$ & $\begin{array}{c}\text { Fire-stopping; } \\
\text { acoustic sealant; } \\
\text { open cell spray } \\
\text { polyurethane foam } \\
\text { (ocSPF) }\end{array}$ \\
\hline
\end{tabular}
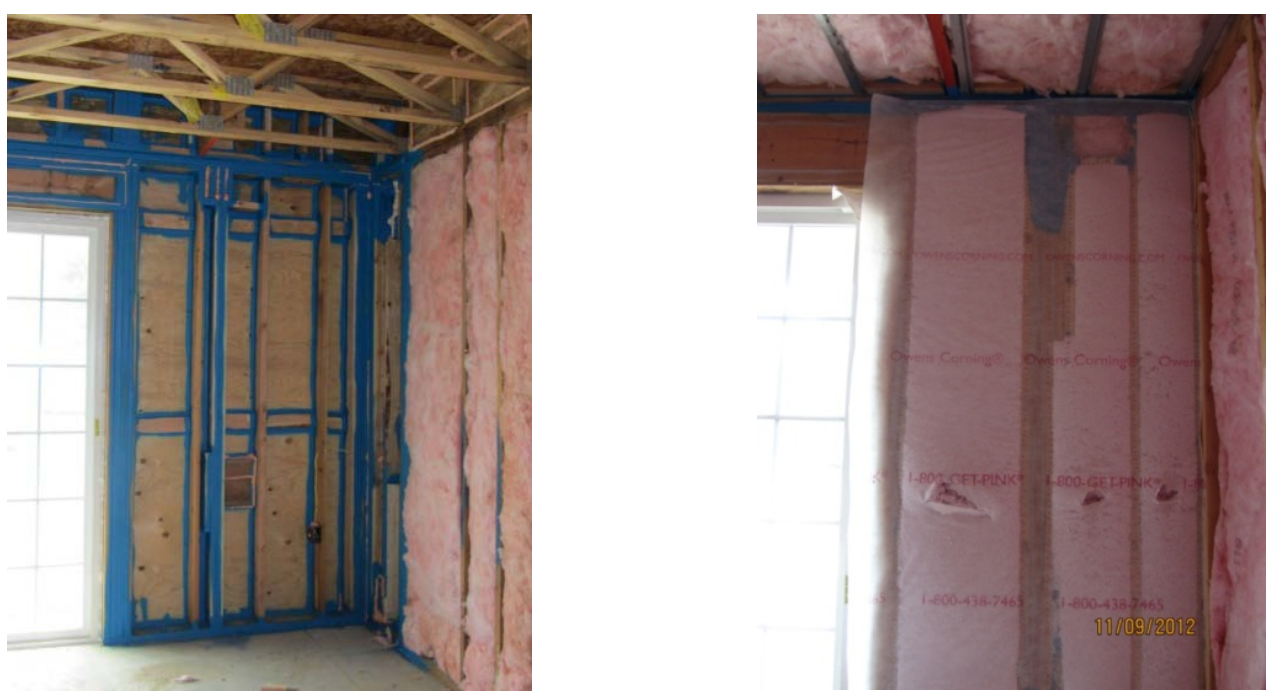

Figure 6. Exterior wall air sealing and insulation used at $\mathrm{CV}$ and $\mathrm{SH}$

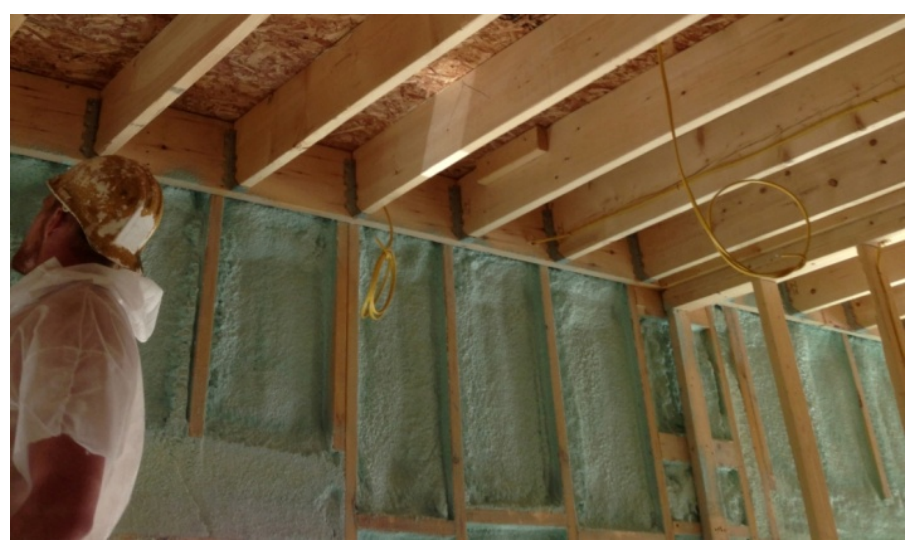

Figure 7. Exterior wall air sealing used at HV 
Air sealing at the demising walls varied considerably between the three buildings. CV implemented a plywood smoke curtain between the trusses above the demising walls (Figure 8); whereas the smoke curtain at the demising walls at $\mathrm{SH}$ was constructed by extending the demising wall sheetrock between the floor joists (Figure 9). At HV the solid floor joists aligned with the demising walls (Figure 10), so a smoke curtain was not necessary (though sealing of wood to wood joints and seams was still needed).

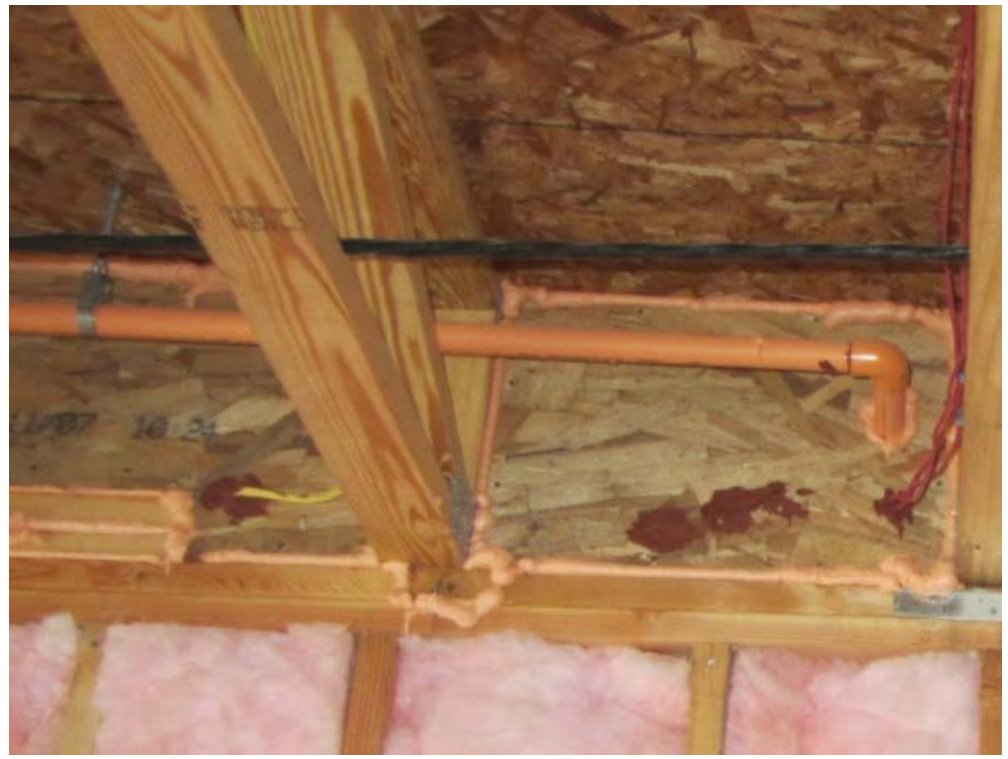

Figure 8. Air sealed plywood smoke curtain used at demising wall of CV

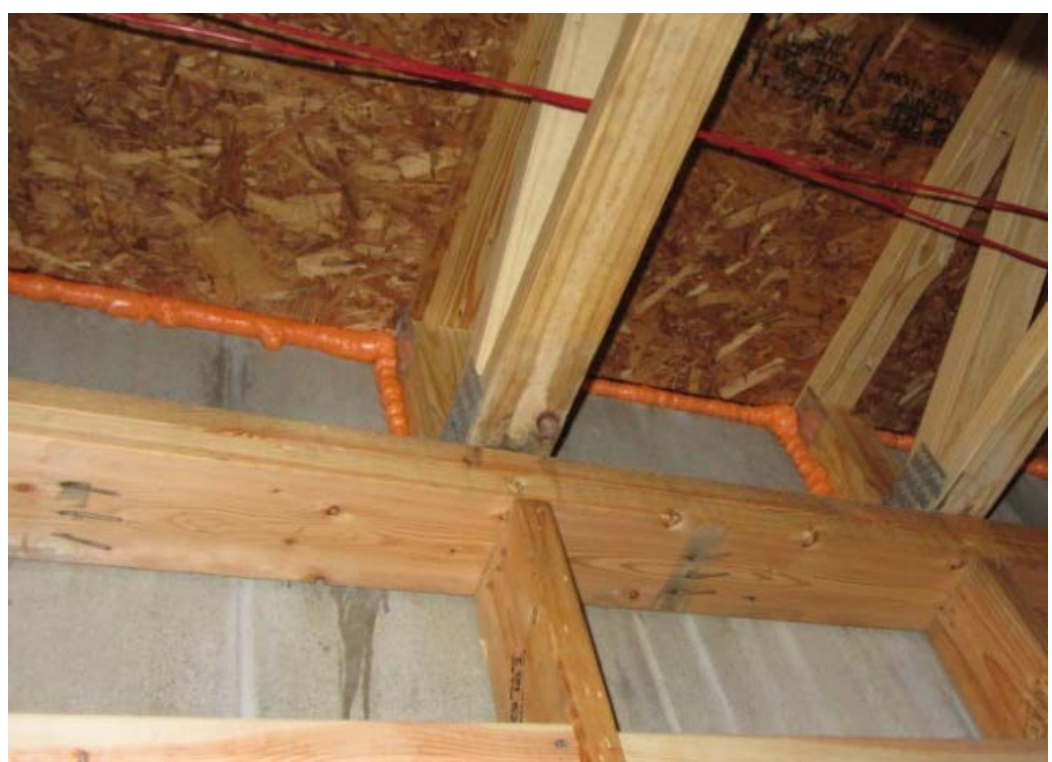

Figure 9. Air sealed sheetrock smoke curtain used at demising wall of $\mathrm{SH}$ 


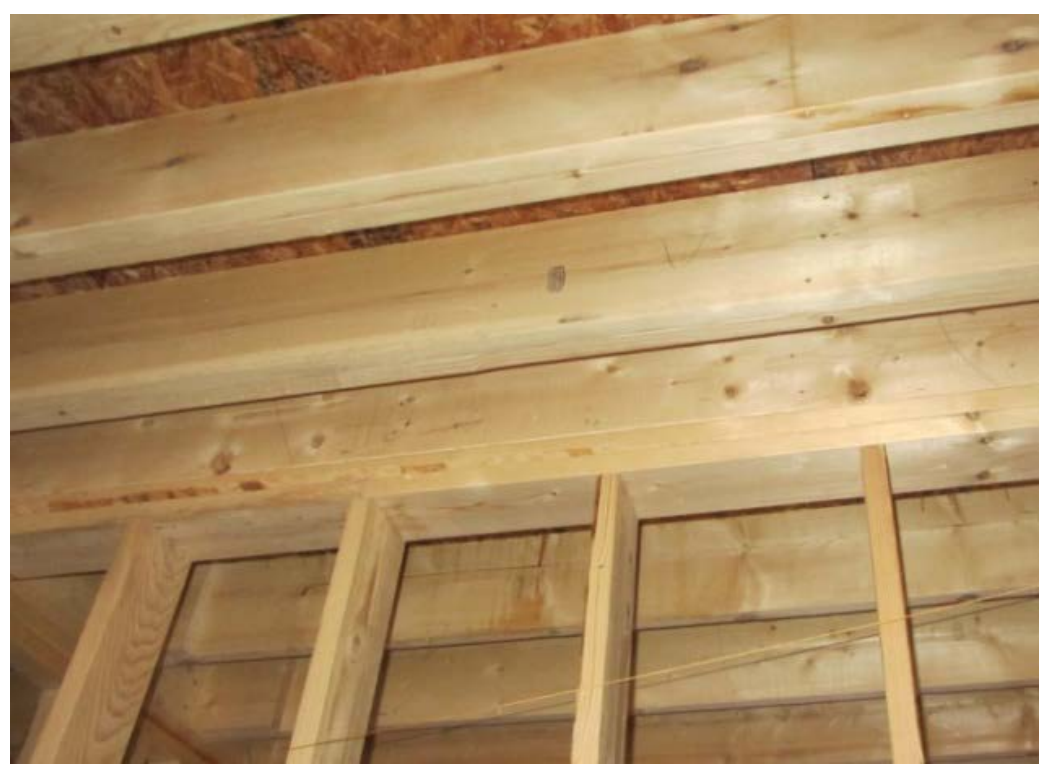

Figure 10. Air sealed structural framing used at demising wall of HV

The builder of CV and SH increased the air sealing scope of work in the SH project due to leakier than expected test results at $\mathrm{CV}$; air sealing in both cases consisted mostly of caulk and expanding foam. The builder at HV has found that ocSPF insulation reliably addresses compartmentalization issues (Figure 11), while providing additional benefits as discussed previously. The increased first cost of the sealing method was offset by reduced labor to air seal and improved quality control, so this sealing strategy is being used at all HV multifamily projects moving forward.

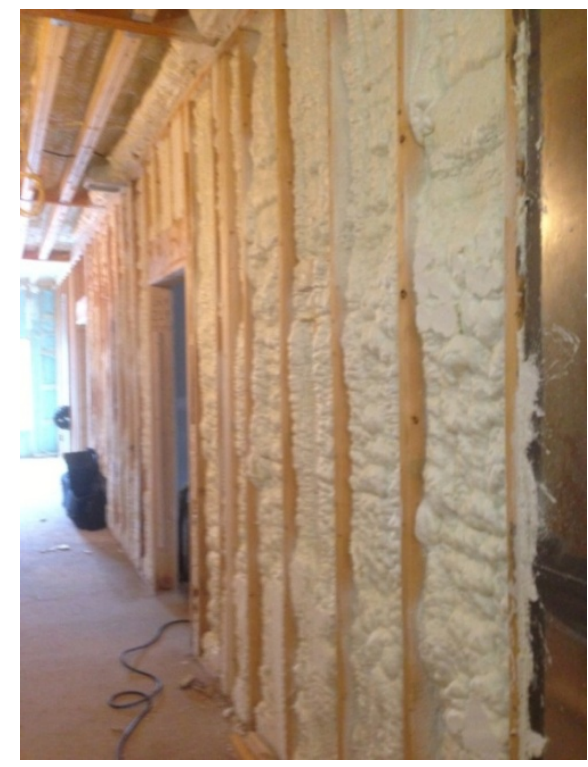

Figure 11. Demising wall air sealing at HV 
A common issue with air sealing of walls is compliance with fire code and rated wall assemblies. According to the builder, in compliance with their local jurisdiction, ocSPF is an approved material for use in a rated bearing wall construction. The design is similar to UL\#U311, with the ocSPF used in lieu of batt insulation. An ICC-ES Evaluation report released in 2010 reviewed and allowed the use ocSPF in a rated wall, provided it was enclosed on both sides of the stud wall with minimum $1 / 2$ in. thick gypsum wall board, attached to the studs with metal fasteners as shown in UL \#311. In this project, $5 / 8$ in. thick gypsum wall board was installed. This method of air sealing dwellings has become the norm in this local region.

\subsection{Dwelling Characteristics}

CARB investigated potential connections between air leakage and various characteristics of the dwellings in each project. The first dwelling characteristic to be analyzed was whether the floor level had an impact on the air leakage rate. Bottom level units have a unit above and a slab below; middle level units have a unit or common area above and below; and top level units have a roof above and a unit below. Figure 12 summarizes this data in a box-and-whisker diagram. The box defines the middle half of data points bounded by the upper quartile and lower quartile. All whiskers represent the greatest and least data value excluding outliers. The circles represent the minimum and maximum outliers. Minimum, maximum, mean, and median $\mathrm{ACH}_{50}$ values are listed below each plot. The percent outliers describe the percentage of the data collected that lies outside the whiskers.

Opposite of what one might anticipate, testing at $\mathrm{CV}$ and $\mathrm{SH}$ showed that air leakage was highest on the bottom level and lowest on the top level. In addition, there was a lower variation (tighter distribution) of the test results on the top level units.

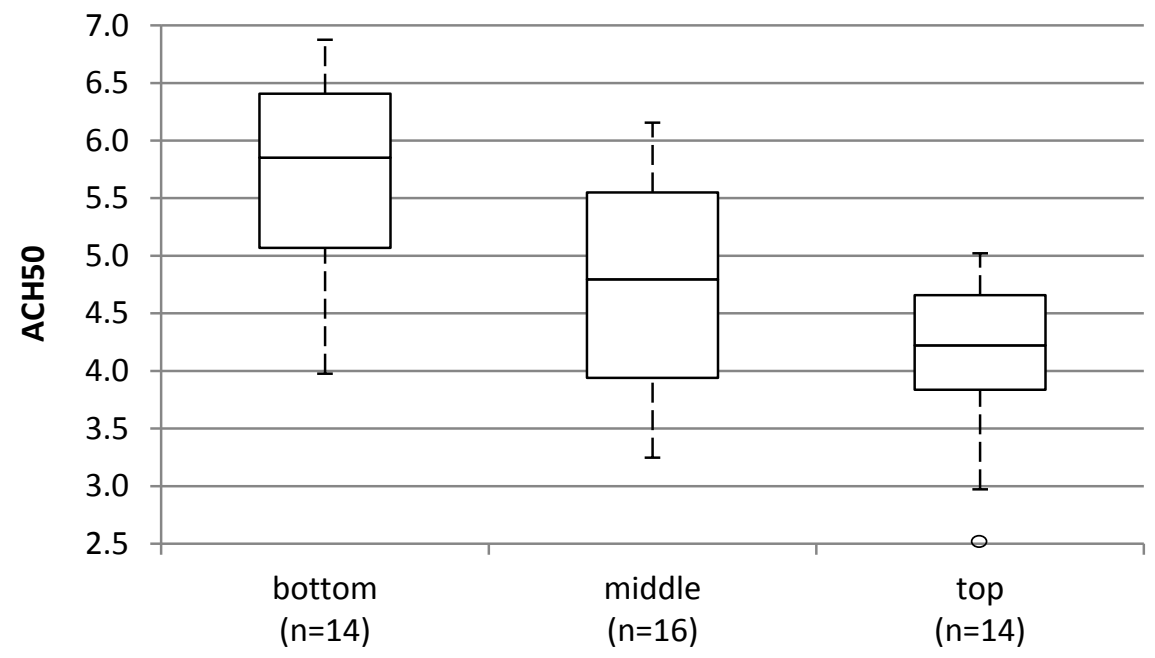

\begin{tabular}{|r|c|c|c|}
\hline Min & 3.98 & 3.25 & 2.97 \\
\hline Max & 6.87 & 6.16 & 5.02 \\
\hline Mean & 5.76 & 4.80 & 4.11 \\
\hline \% Outliers & 5.85 & 4.80 & 4.22 \\
\hline
\end{tabular}

Figure 12. Unguarded $\mathrm{ACH}_{50}$ values by unit level at $\mathrm{CV}$ and $\mathrm{SH}$ 
At $\mathrm{CV}$, the air sealing crews started at the top of the building and worked their way down through the building. Unfortunately, they were rushed for time by the time they got to the lower levels and the quality control of the air sealing efforts suffered. It is unclear why SH showed this same trend, as the air sealing crew was not rushed for time for this building. The top level being the tightest is likely a result of all the buildings paying special attention to the critical air sealing of the ceiling plane. CV has a sheetrock ceiling for mechanical, electrical, and plumbing, then another layer of sheetrock before the blown cellulose in attics. SH did not have the double sheetrock ceiling, but did air sealing at attic penetrations before blown cellulose. Both are rigid on the flat roof sections where equipment sits.

Another dwelling characteristic, the location of a dwelling within the footprint of a building, was anticipated to have a noticeable impact on air leakage, as the characteristics of the exterior surfaces typically differ from the characteristics of the adiabatic surfaces. However, from this small sample set, the impact on air leakage was not significant. Figure 13 shows the relationship between dwellings located toward the interior of the building and dwellings located at the ends of the SH building. The end dwellings had a slightly higher mean air leakage value as well as a larger variation in test results, even though these dwellings were considerably outnumbered by the interior dwellings.

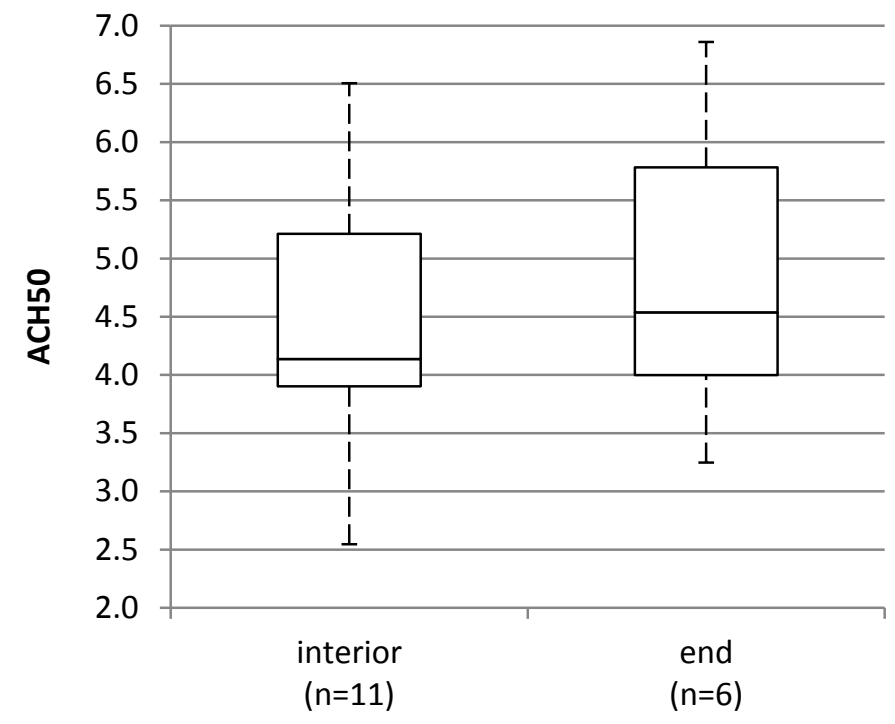

\begin{tabular}{|r|c|c|}
\hline Min & 2.55 & 3.25 \\
\hline Max & 6.51 & 6.86 \\
\hline Mean & 4.36 & 4.83 \\
\hline \% Outliers & 4.14 & 4.54 \\
\hline
\end{tabular}

Figure 13. Unguarded $\mathrm{ACH}_{50}$ values by location at $\mathrm{SH}$

The CV building showed a noticeable difference in air leakage between units that are neighbored by other units versus units neighbored by non-unit areas such as amenity areas, chases, and shafts. This analysis was done in the horizontal plane only (i.e., across walls rather than ceilings 
or floors). At walls between two units, both sides of the wall are most likely air sealed, whereas only one side is typically sealed at walls between units and non-unit spaces, resulting in a reduction in air leakage as shown in Figure $14(\mathrm{NNU}=$ units neighbored by non-unit areas; $\mathrm{NU}=$ units neighbored by other units).

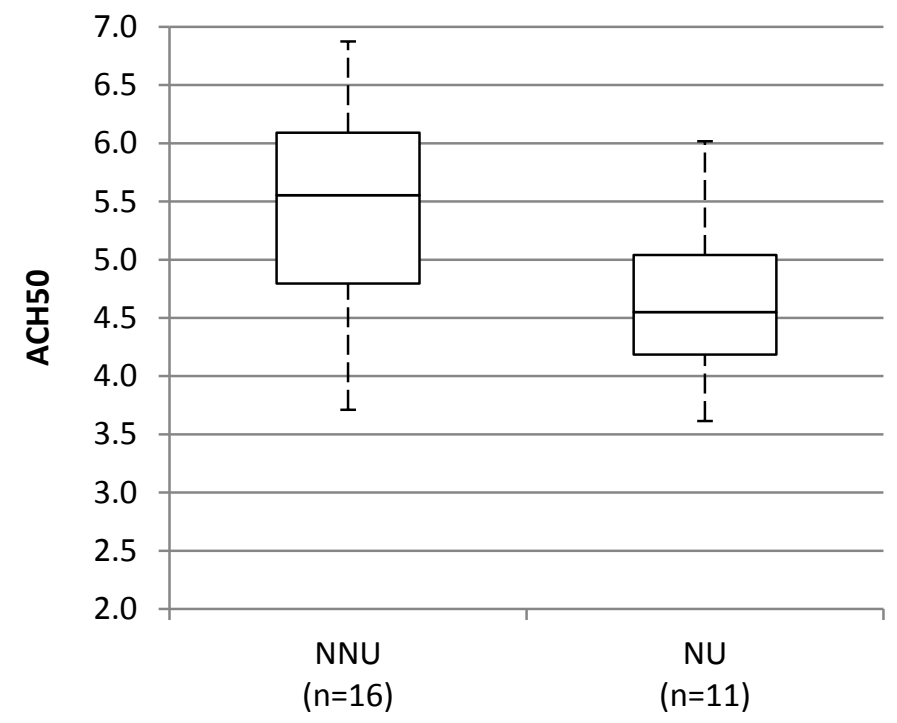

\begin{tabular}{|r|c|c|}
\hline Min & 3.71 & 3.61 \\
\hline Max & 6.87 & 6.02 \\
\hline Mean & 5.42 & 4.65 \\
\hline \% Outliers & 5.55 & 4.55 \\
\hline
\end{tabular}

Figure 14. Unguarded $\mathrm{ACH}_{50}$ values by unit location at $\mathrm{CV}$

\subsection{Cost Effectiveness}

BEopt $^{\mathrm{TM}}$ software (Building Energy Optimization version 2.1) evaluates residential building designs and identifies cost-optimal efficiency packages at various levels of whole-house energy savings. The annual energy-related cost (AERC) can be obtained by annualizing the energyrelated cash flows (mortgage payments and utility bills) over an analysis period of 30 years. Inputs for the various economic variables, as defined by the Addendum to the Building America House Simulation Protocols (Metzger et al. 2012), are shown in Table 2. 
Table 2. Inputs of Economic Analysis

\begin{tabular}{|c|c|}
\hline Economic Variables & Modeling Inputs \\
\hline Project Analysis Period & 30 years \\
Inflation Rate & $2.4 \%$ \\
\hline Discount Rate (Real) & $3.0 \%$ \\
\hline Loan Period & 30 years \\
\hline Loan Interest Rate & $4.0 \%$ \\
\hline Marginal Income Tax Rate (Federal/State) & $28 \% / 0 \%$ \\
\hline Electricity Rate* & $\$ 0.14 /$ kilowatt-hour \\
\hline Natural Gas Rate & $\$ 1.03 /$ therm \\
\hline Fuel Escalation Rate & $0.0 \%$ \\
\hline
\end{tabular}

* Twelve-month average for upstate New York

CARB modeled a middle-floor, $1,120-\mathrm{ft}^{2}$ end unit in climate zone 5 according to IECC 2012 as shown in Table 3. Benchmark defaults as outlined in the Addendum to the Building America Housing Simulation Protocols (Metzger et al. 2012) were used for options not mandated by the 2012 IECC. The dwelling unit was modeled at eight varying air leakage levels ranging from 7 to $0.5 \mathrm{ACH} 50$ to investigate the effects of air leakage on energy and cost. BEopt uses the Alberta air infiltration model (AIM-2) to determine hourly, weather-dependent infiltration rates. Still, this energy simulation is geared for modeling of a single dwelling unit and doesn't account for the multifamily building interactions (air leakage between units, stack effects, etc.), so there are significant limitations that need to considered when drawing conclusions from this analysis.

Table 3. Model Home Options

\begin{tabular}{c|c}
\hline Category & Description \\
\hline Walls & R-13 fiberglass batts, grade I, $2 \times 4$ studs @ 16 in. on center \\
\hline Wall Sheathing & oriented strand board, R-5 extruded polystyrene \\
Windows & $\begin{array}{c}\text { Double-pane, high gain low-emissivity, insulated frame, } \\
\text { air filled U }=0.29, \text { solar heat gain coefficient }=0.56\end{array}$ \\
\hline Air Leakage & $3.0 \mathrm{ACH}_{50}$ \\
\hline $\begin{array}{c}\text { Ventilation } \\
\text { Appliances, Lighting } \\
\text { Cooling System }\end{array}$ & Exhaust only, $100 \%$ ASHRAE 62.2-2010 \\
\hline Heating System & Benchmark \\
\hline Ducts & Seasonal energy efficiency ratio 13 \\
\hline Water Heater & Gas furnace, $78 \%$ annual fuel utilization efficiency \\
\hline
\end{tabular}

The AERC for the modeled home at each infiltration level is shown Figure 15. As expected, decreasing $\mathrm{ACH}_{50}$ values correlate with lower annualized energy-related cost, while capital costs increase. The estimated annualized energy-related cost savings from $7 \mathrm{ACH}_{50}$ (IECC 2009 code) to $3 \mathrm{ACH}_{50}\left(\mathrm{IECC} 2012 \mathrm{ACH}_{50}\right)$ decreases by $2.8 \%$ ( $\$ 35 /$ year), but this comes with a $0.35 \%$ (\$150) increase in capital costs. Base on cost information from the National Residential Efficiency Measures Database, the energy modeling analysis suggests that the additional savings benefit in AERC decreases beyond $3 \mathrm{ACH}_{50}$, while the capital costs to achieve the lower air leakage value continue to rise. 


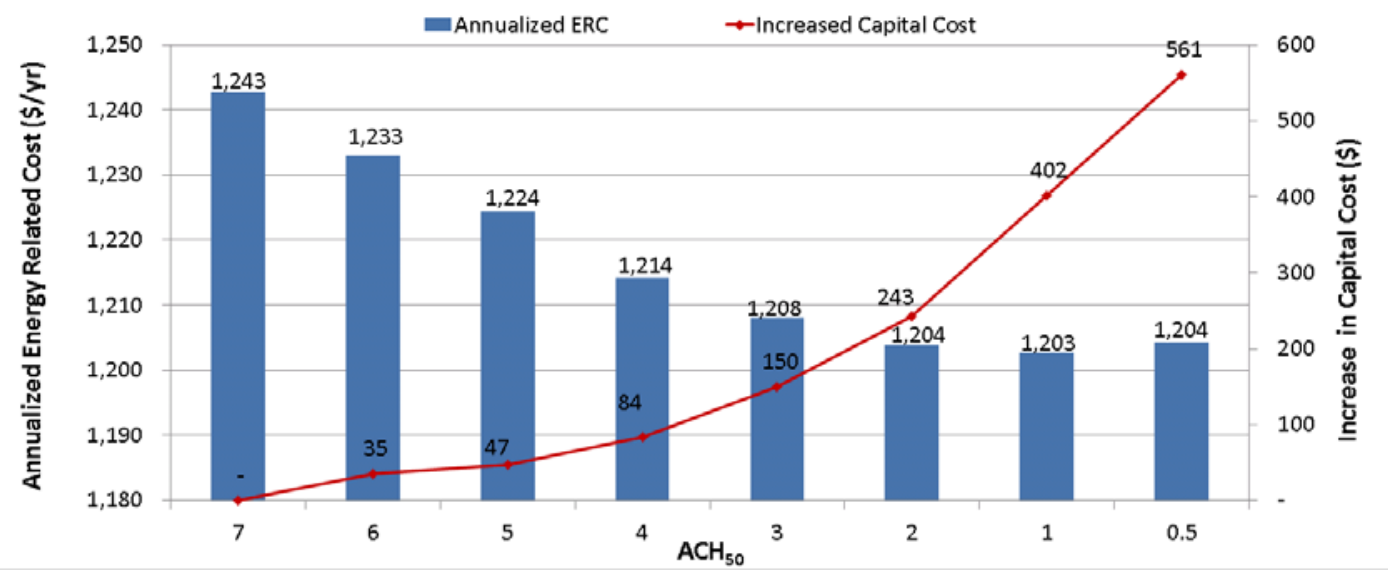

Figure 15. Annualized energy-related cost at decreasing $\mathrm{ACH}_{50}$ values

Actual capital costs for air leakage reduction were not available; however, CARB attained whole-building insulation and air sealing costs for each project, as shown in Table 4. By utilizing the same crew and making minor adjustments to the insulation and air sealing strategies, the construction team for $\mathrm{CV}$ and $\mathrm{SH}$ was able to decrease air leakage at a lower cost at the second building. In contrast, the insulation and air sealing costs are considerably higher at HV (due to use of ccSPF), but the resulting air leakage is significantly lower.

Table 4. Insulation/Air Sealing Cost per Unit Versus Mean $\mathbf{A C H}_{50}$

\begin{tabular}{c|c|c|c}
\hline & $\mathbf{C V}$ & $\mathbf{S H}$ & $\mathbf{H V}$ \\
\hline Mean $\mathbf{A C H}_{\mathbf{5 0}}$ & 5.1 & 4.5 & 3.0 \\
Estimated \$/Unit & $\$ 2,371$ & $\$ 1,376$ & $\$ 2,910$ \\
\hline
\end{tabular}

The question comes down to whether it is more advantageous for the builders to spend money on compartmentalization or guarded blower door testing of each unit. Community Housing Partners out of Virginia are one of the most experienced companies performing larger scale guarded blower door testing on attached homes and multifamily dwellings. According to Community Housing Partners, testing every unit of a $\sim 100$ unit building would cost $\$ 300-\$ 350$ /unit and take roughly a week to test straight through utilizing up to nine blower doors at a time. This assumes that Community Housing Partners could go straight through without interference from others (builder, contractors, etc.), which is not typically possible in new construction buildings. 


\section{Results}

\subsection{How Achievable Is the 2012 IECC Climate Zone 3-8 Infiltration Value of $3 \mathrm{ACH}_{50}$ in Multifamily Dwellings When Accounting for Unguarded Blower Door Testing?}

HV had the highest percentage of units (50\%) that met the 2012 IECC air leakage requirement of $3 \mathrm{ACH}_{50}$ based on unguarded blower door testing. Twelve percent of units at $\mathrm{SH}$ met the requirement, and none of the units at $\mathrm{CV}$ met the requirement.

Figure 16 shows box plots of the distribution of $\mathrm{ACH}_{50}$ values for each project using a $30 \%$ air leakage reduction for estimated guarded values (based on the literature search, which showed a $20 \%-30 \%$ reduction from unguarded to guarded testing). Out of the 58 test apartments, only 11 units met the 2012 IECC $3 \mathrm{ACH}_{50}$ requirement via unguarded testing. An additional 23 units passed when the estimated guarded value was applied. That still leaves roughly $40 \%$ of the units failing the airtightness requirement of the 2012 IECC. Based on the current language of the 2012 IECC, it is likely that a combination of enhanced air sealing and guarded blower door testing may be required. This suggests that specific air leakage requirements for multifamily dwellings may be worth consideration.

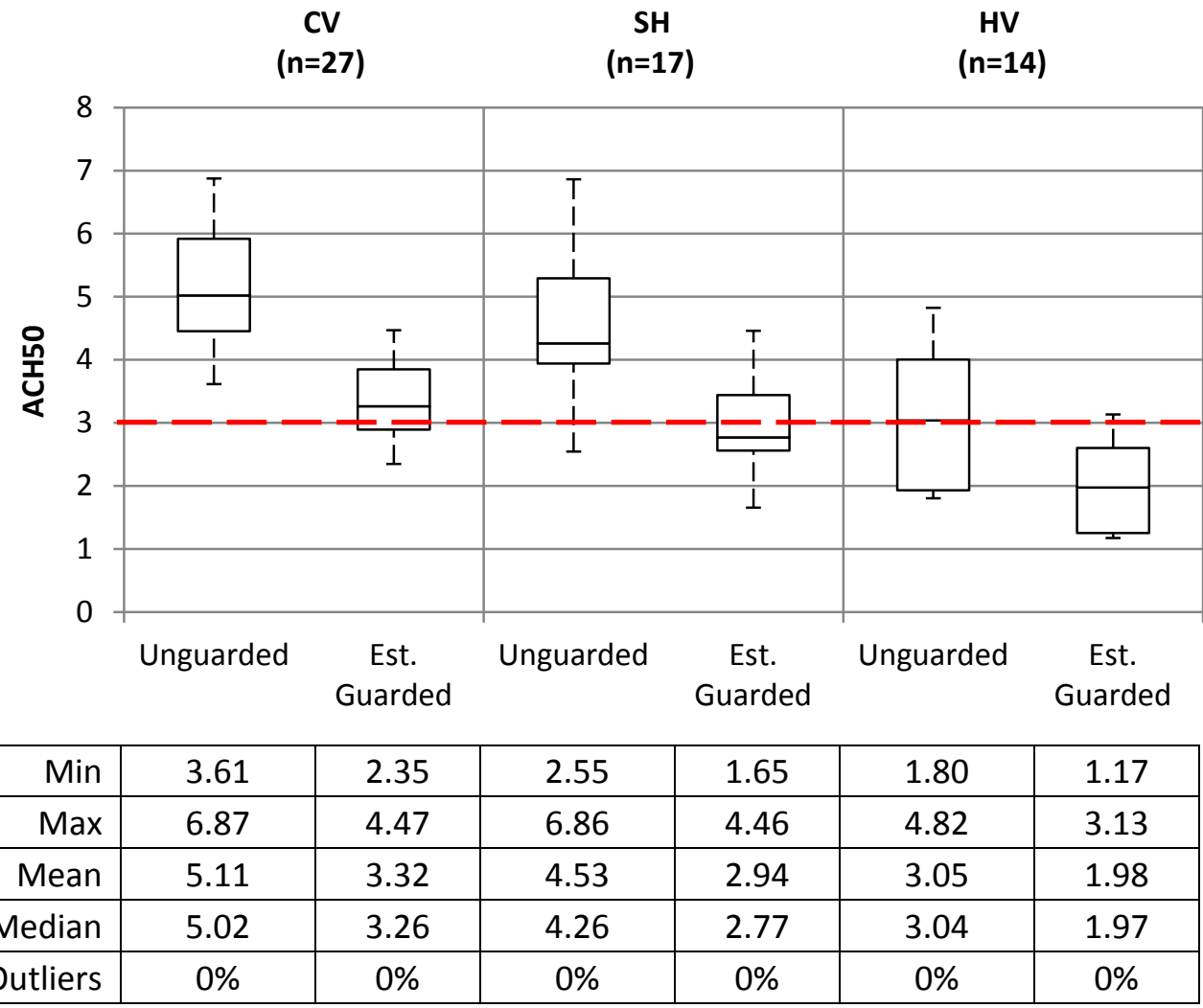

Figure 16. $\mathrm{ACH}$ values from both unguarded and estimated guarded testing

While the builders were interested in evaluating the level of effort required to achieve $3 \mathrm{ACH}_{50}$ in these dwelling, it is important to note that none of the projects were required to achieve 3 ACH50. These projects were enrolled in the New York State Energy Research and 
Development Authority Low-rise Residential New Construction Program (PON 2309). This program includes an air leakage requirement based on the surface area of each apartment rather than the volume of each apartment. Though not utilized by IECC for homes, this $\mathrm{CFM}_{50} / \mathrm{ft}^{2}$ of enclosure surface area is CARB's preferred metric, as the goal is to seal air leaks through all the surfaces that make up a building's shell and not within the entire volume of a home.

The passing threshold, $\leq 0.3 \mathrm{CFM} 50 / \mathrm{ft}^{2}$ of enclosure surface area, takes into account the fact that attached dwelling enclosures include adiabatic AND exterior surfaces, and a portion of air leakage through the enclosure may have a relatively small effect on energy performance. Using the surface area-based air leakage metric and target, all dwellings units tested in these three projects met this criterion (Figure 17).

While a direct correlation between the volume-based metric $\left(\mathrm{ACH}_{50}\right)$ and the enclosure-based metric $\left(\mathrm{CFM}_{50} / \mathrm{ft}^{2}\right.$ of enclosure surface area) cannot be made due to the unique characteristics of each apartment, for the apartments in this study, $0.3 \mathrm{CFM} 50 / \mathrm{ft}^{2}$ was approximately equivalent to 6-7 ACH50.

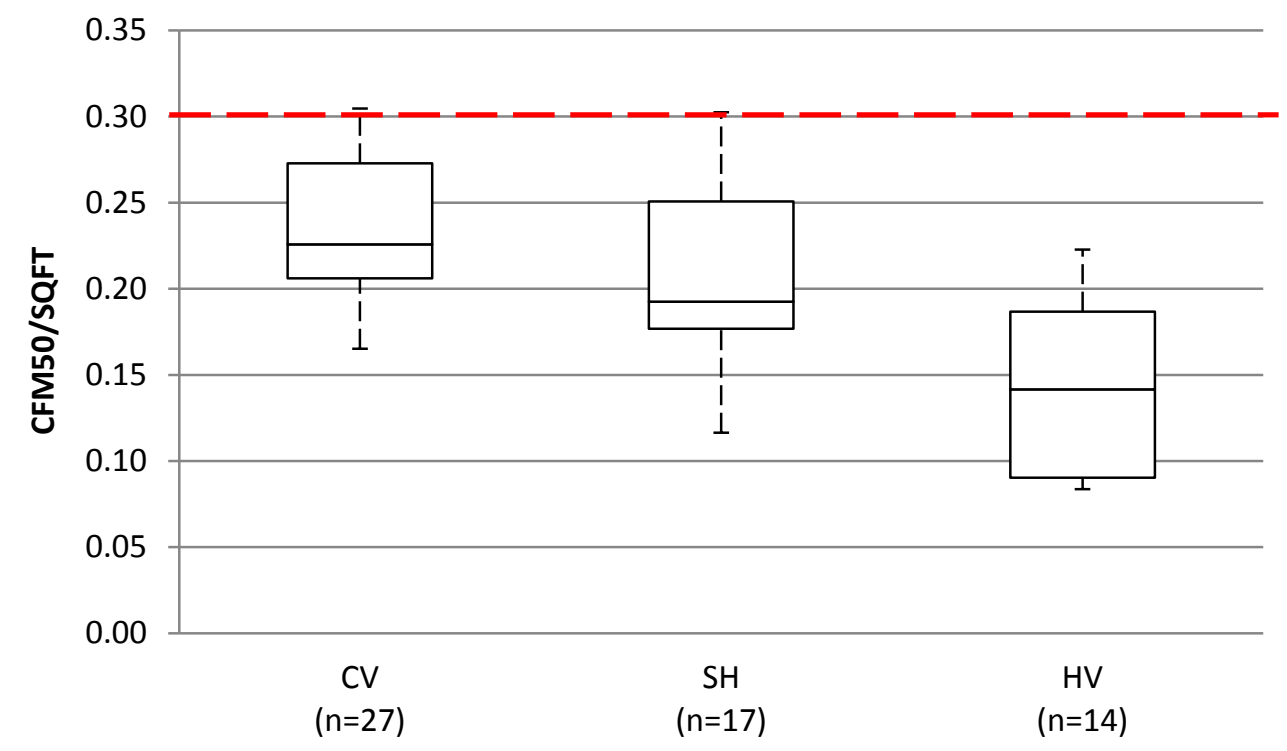

\begin{tabular}{|r|c|c|c|}
\hline Min & 0.17 & 0.12 & 0.08 \\
\hline Max & 0.30 & 0.30 & 0.22 \\
\hline Mean & 0.24 & 0.20 & 0.14 \\
\hline \%edian & 0.23 & 0.19 & 0.14 \\
\hline
\end{tabular}

Figure 17. Unguarded $\mathrm{CFM}_{50} / \mathrm{ft}^{2}$ of enclosure area

\subsection{What Insulation/Air Sealing Strategies Help Buildings Achieve the 2012 IECC Air Leakage Requirement?}

Due to the number of variables between the characteristics of each of the buildings, distinct strategies for achieving the 2012 IECC air leakage requirement cannot be directly identified. 
However, the sequential improvement in testing results provides some insight into identifying the strategies for reducing air leakage.

The use of spray polyurethane foam insulation at HV clearly resulted in lower air leakage values; CARB believes that the greatest benefit from this material may be earned by using it at adiabatic walls in addition to exterior walls. The downside to using this material, however, includes increased costs and construction scheduling conflicts. Regardless, the HV builder has found that the benefits of spray polyurethane foam insulation, including those in addition to air sealing, warrant using this material for all of its multifamily projects.

The additional air sealing tasks performed at SH (compared to CV) definitely resulted in lower air leakage results. These tasks primarily applied to penetrations in the drywall, such as at piping and ductwork.

The characteristics of the units within each building had a modest effect on air leakage.

- In regard to building level, the top floor units performed better than bottom floor units, which may be attributed to the exposure of the horizontal surfaces above and below the units.

- A building with a generic rectangular plan will have fewer end units than a building with several corners, which would likely reduce air leakage due to minimized exposed area.

- Dwellings neighbored by non-unit areas, such as amenity areas, chases, and shafts, tended to not be as airtight. Sealing the walls of non-unit areas similar to dwellings could potentially reduce air leakage.

\subsection{What Lessons Can Be Learned From the Air Sealing/Insulating Techniques Employed in These Projects?}

The builder and Home Energy Rating Systems rater for CV and SH agree that the improvement in air leakage values at $\mathrm{SH}$ is rooted in lessons learned at $\mathrm{CV}$.

- Due to unsatisfactory test results at $\mathrm{CV}$, the construction team made air sealing a priority at $\mathrm{SH}$; the various subcontractors were given additional time to perform the air sealing tasks, and the builder and rater provided additional oversight and support.

- In addition, the insulation subcontractor at $\mathrm{SH}$ was given full responsibility for all air sealing, whereas multiple subcontractors were responsible for air sealing at $\mathrm{CV}$.

Unfortunately this additional effort is not easily quantified; regardless, CARB believes that a heightened level of awareness led to better results at the second building.

From an architectural standpoint, design decisions can be made to help reduce air leakage throughout the development process.

- As mentioned above, the layout of the units (exposed surface area) within a building can affect air leakage. 
- The architect should also be familiar with a variety of air sealing techniques; incidentally, a large number of techniques in SWA's air sealing guides were not implemented in any of the projects in this study.

- Adding air leakage thresholds and responsibilities to the contract documents will make bidders more aware of air sealing expectations. 


\section{Discussion}

\subsection{What Other Techniques Could Have Been Used To Reduce Air Leakage?}

Builders choose to implement various air leakage reduction techniques based on feasibility, cost, and experience. Some techniques, such as making access panels airtight (Figure 21), are relatively low in cost and easy to do; since this task can be completed at any time, however, builders will commonly wait to perform this task until after its necessity has been determined. Other techniques, such as separating wall cavities with a layer of drywall (Figure 20), are often rejected by design teams due to structural constraints. Generally, builders will not incorporate new or unfamiliar techniques until they are required to do so. SWA's air sealing guides include several strategies not implemented in these projects, as described below. An updated air sealing guide for wood construction multifamily projects is included as the Appendix.

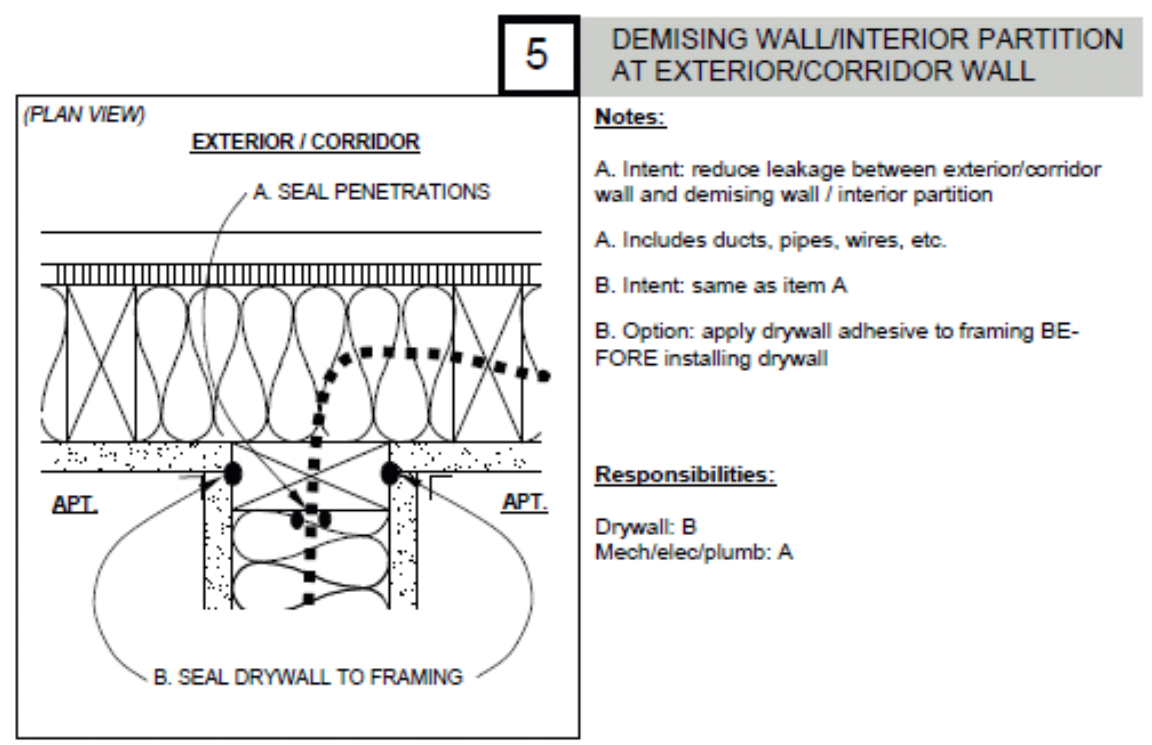

Figure 18. Air sealing detail-seal drywall to framing at wall intersections

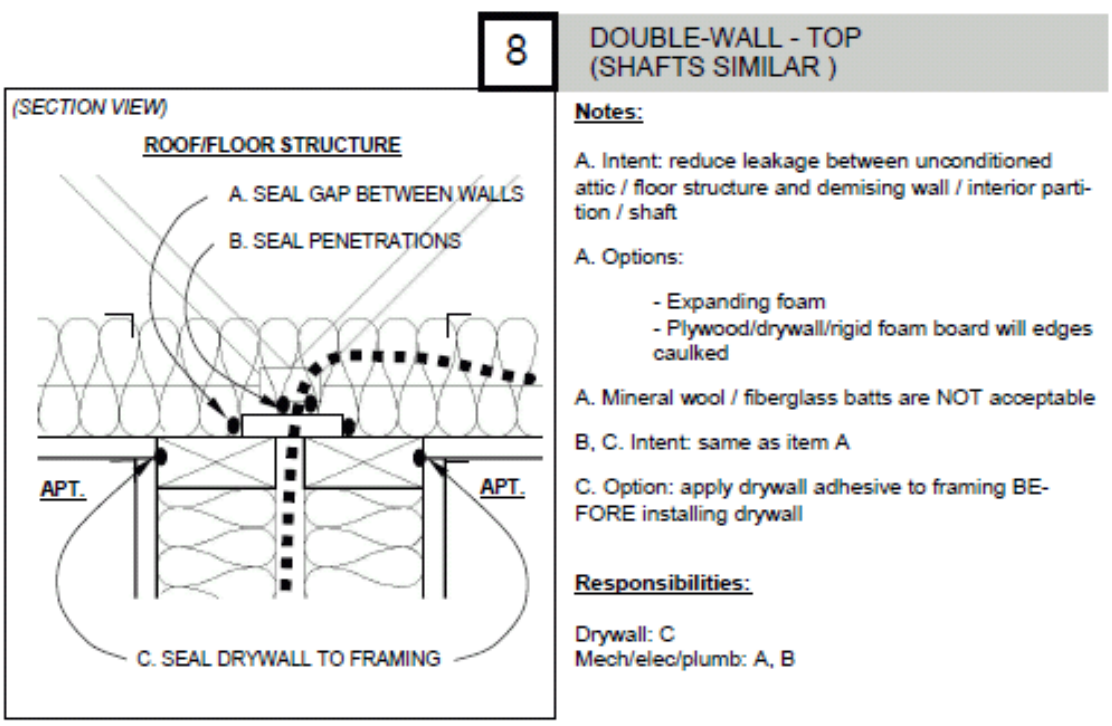

Figure 19. Air sealing detail-seal top of double-framed walls 


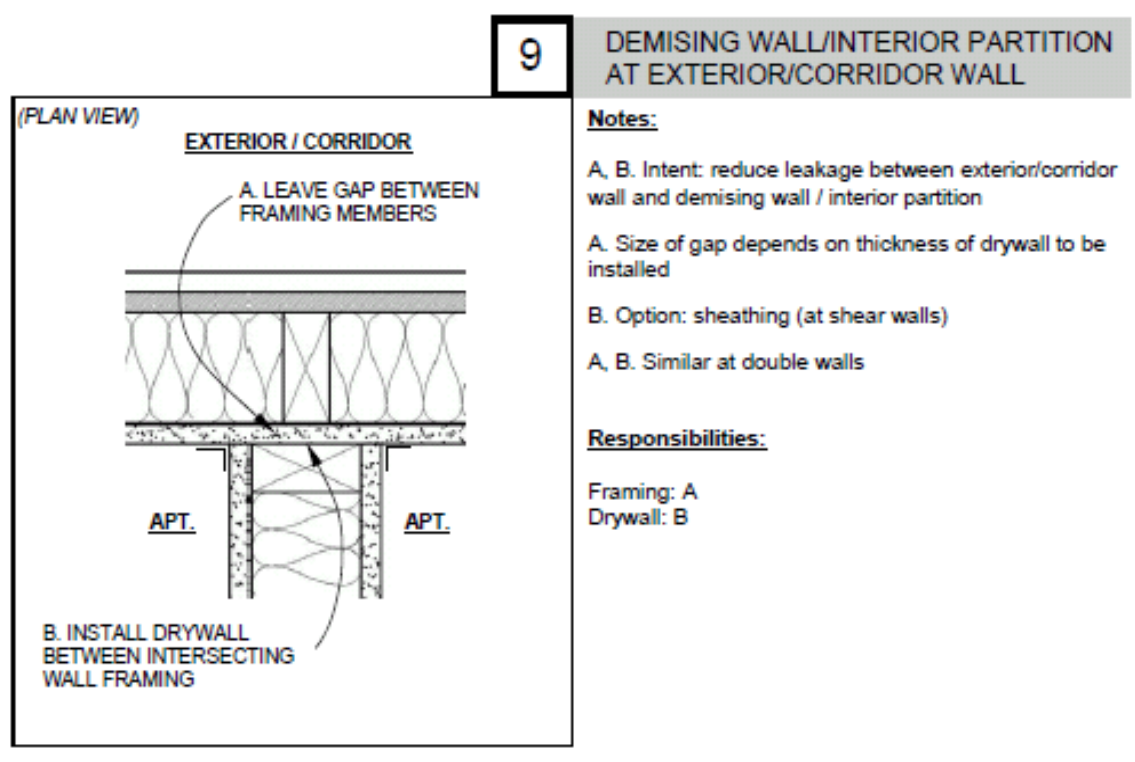

Figure 20. Air sealing detail-separate framing cavities with drywall

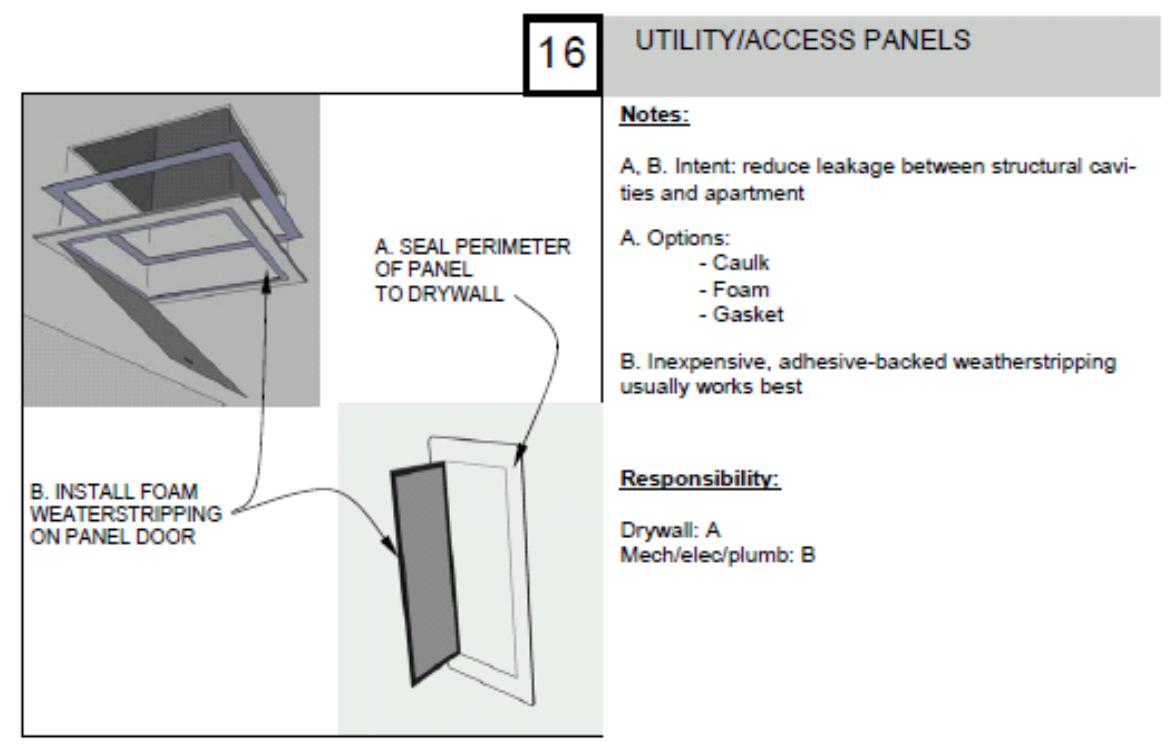

Figure 21. Air sealing detail-seal access panels

\subsection{To Meet the 2012 IECC Air Leakage Requirement, Should Builders Spend Money on Air Sealing or Guarded Testing?}

Based on CARB's findings, meeting the 2012 IECC air leakage requirement will require builders to put more effort toward reducing air leakage in multifamily dwellings. The responsibility for this effort could be focused in two possible directions: improving the air sealing scope of work (thereby reducing air leakage), or employing alternative testing techniques (guarded blower door testing). 
Reducing air leakage between spaces in a multifamily building has several ancillary benefits:

- Increased smoke/fire control

- Increased occupant comfort, including reduced odors, drafts, and sound transmission

- Greater control and effectiveness of heating, ventilation, and air conditioning systems

- Increased overall building performance (reduced air leakage within the building helps reduce pressure differentials and therefore heat loss due to stack effect, wind, etc.).

The difference in testing results between $\mathrm{CV} / \mathrm{SH}$ and $\mathrm{HV}$ could easily be attributed to the exclusive use of sprayed polyurethane foam insulation; obviously this reduction in air leakage comes at considerable cost. Other less expensive techniques may achieve similar results; however, these techniques (as outlined in Section 7.1) were not implemented, and the associated construction costs are not available.

From the builder's standpoint, employing alternative testing techniques may seem like a better approach. Instead of adding more tasks to the subcontractors' already substantial scope of work, the responsibility would fall to the rater to confirm the requirements after the majority of work has been completed.

In regard to construction costs, the builder would be required to weigh hard costs (improving the air sealing scope of work) against soft costs (paying the rater to perform more tests). Due to the multitude of air sealing techniques and testing costs, this comparison can only be done on a caseby-case basis.

It should be noted that in addition to the loss of ancillary benefits mentioned above, relying on guarded blower door testing is not a fail-safe strategy. Depending on assembly techniques, depressurizing all of the spaces adjacent to the apartment being tested may be unfeasible; these spaces include non-apartment spaces such as corridors and assembly areas, as well as interstitial spaces such as contiguous truss cavities.

\subsection{Should the IECC Air Leakage Requirement Be Based on Enclosure Area Rather Than Volume?}

While CARB believes the goals of the 2012 IECC air leakage requirement are desirable, there is concern that this requirement is geared toward single-family construction only and doesn't address the nuances of multifamily construction. Rather than quantifying air leakage based on a dwelling's volume, one might argue that air leakage should be quantified based on how much of a dwelling's enclosure area is exposed to ambient conditions. This idea has implications for both attached and detached dwellings.

In any dwelling, energy loss occurs at the exterior enclosure, and the relationship between the dwelling's enclosure and its volume is not constant. For example, a dwelling with an elongated plan will have a larger enclosure area than a square-shaped dwelling of the same floor area (Figure 22). 


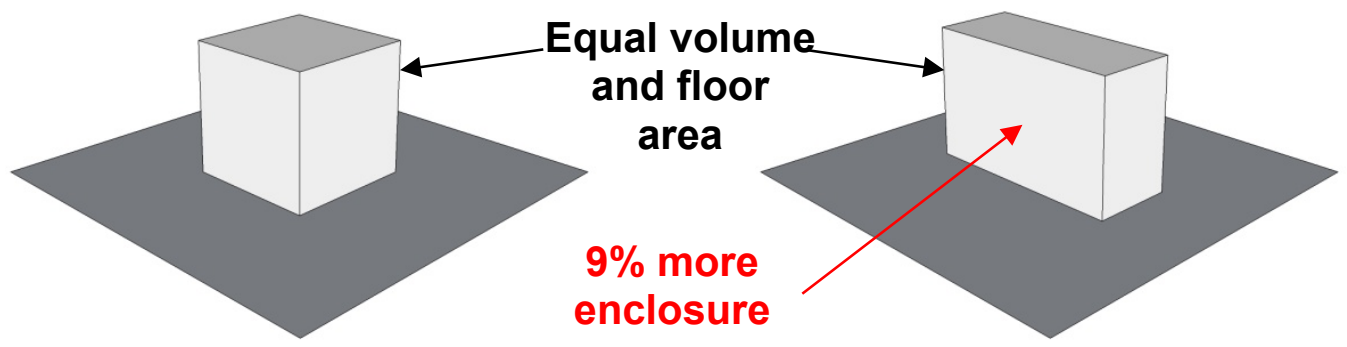

Figure 22. Comparison of dwelling volume and area

The discrepancy in exterior enclosure area is even greater when comparing attached and detached dwellings. Assuming the abstract dwellings shown earlier in Figure 1 have the same shape and volume, the exterior enclosure of the attached dwelling is a small fraction of the exterior enclosure of the detached dwelling.

CARB proposes the following exception for multifamily buildings (a building containing multiple dwelling units), which also includes an option for test sampling:

Exception: For low-rise multifamily buildings, dwelling units shall be tested and verified as having a leakage rate of not exceeding 0.25 cubic feet per minute (cfm) per square foot of enclosure area (all six sides of the dwelling unit) in Climate Zone 1 through 8. Testing shall be conducted with an unguarded blower door at a pressure of 0.2 inches w.g. (50 Pascal). If guarded blower door testing (a test with one or more adjacent units pressurized, which should eliminate any leakage between units) is being performed, this exception is not allowed and the standard testing requirements of Section 402.4.1.2 apply. Where required by the code official, testing shall be conducted by an approved third party. For buildings with more than 7 units, a sampling protocol is allowed by an approved third party. The sampling protocol requires the first seven units to be tested without any failures. Upon successful testing of those initial seven units, remaining units can be sampled at a rate of 1 in 7. If any sampled unit fails compliance with the maximum allowable air leakage rate, two additional units in the same sample set must be tested. If additional failures occur, all units in the sample set must be tested. In addition, all units in the next sample set must be tested for compliance before sampling of further units can be continued.

The same requirement is being proposed for all climates for simplicity as the metric is shifting from air leakage to outside to compartmentalization. In addition, the $0.25 \mathrm{cfm}_{50} / \mathrm{ft}^{2}$ of enclosure area roughly equates to $4.5-5.5 \mathrm{ACH}_{50}$ for typical size apartment dwellings, which is similar to the airtightness rate currently specified by the 2012 IECC for climate zones $1-3$. 


\section{Conclusion}

Achieving an unguarded $3 \mathrm{ACH}_{50}$ in multifamily dwellings is not easy.

- Reducing air leakage starts during the design development process; design teams must make decisions that allow for the air leakage requirement to be met.

- Construction teams must understand the design teams' intent while incorporating their experiences from previous successes and failures. Implementation is crucial; subcontractors will not meet their air leakage reduction goals without heightened awareness, support and oversight.

- Until design and construction teams become familiar and comfortable with the tasks required to meet the air leakage requirement, construction costs will almost certainly increase.

However, achieving $3 \mathrm{ACH} 50$ is not impossible. With the right combination of design, investment and implementation, meeting the 2012 IECC requirement for air leakage is definitely feasible. 


\section{References}

BECP (2011). Air Leakage Guide: Meeting the Air Leakage Requirements of the 2012 IECC. U.S. Department of Energy's Building Energy Codes. PNNL-SA-82900. Accessed December 23, 2013:

http:/www.energycodes.gov/sites/default/files/documents/BECP Buidling\%20Energy\%20Code \%20Resource\%20Guide\%20Air\%20Leakage\%20Guide Sept2011 v00 lores.pdf.

Brennan, T.; Clarkin, M.; Nelson, G., Olson, C.; Morin, P. (2014). Blower Door Applications Guide: Beyond Single Family Residential. Minneapolis, MN: The Energy Conservatory. Edition 1.0. Accessed April 22, 2014: http:/www.energyconservatory.com/sites/default/files/documents/ blower_door_applications_guide - beyond single family_residential_ver_1-0 0.pdf.

Dentz, J.; Conlin, F. (2012). Air Leakage Testing and Air Sealing in Existing Multifamily Units. Advanced Residential Integrated Energy Solutions. DOE/GO-102012-3583. Accessed April 24, 2012: http://apps1.eere.energy.gov/buildings/publications/ pdfs/building america/air sealing multifamily.pdf.

Faakye, O.; Arena, L.; Griffiths, D. (2013) Predicting Envelope Leakage in Attached Dwellings. Consortium for Advanced Residential Buildings. DOE/GO-102013-3939. July 2013. Accessed December 19, 2013: http://carb-swa.com/Collateral/Documents/CARB-SWA/ Research/Predicting Envelope Leakage.pdf.

Gadgil, A.; Price, P.N.; Shehabi, A.; Chan, R. (2006). Indoor-Outdoor Air Leakage of Apartments and Commercial Buildings. CEC-500-2006-111. Berkeley, CA: Lawrence Berkeley National Laboratory. Accessed April 24, 2014:

http://www.energy.ca.gov/2006publications/CEC-500-2006-111/CEC-500-2006-111.PDF.

IECC (2009). 2009 International Energy Conservation Code, Section 402.4 "Air Leakage." Washington, DC.: International Code Council. www.iccsafe.org/Store/Pages.

IECC (2012). 2012 International Energy Conservation Code, Section 402.4 "Air Leakage," International Code Council (ICC), Washington, DC. www.iccsafe.org/Store/Pages.

Lstiburek, J. (2005). "Multifamily Buildings: Controlling Stack-Driven Airflows." ASHRAE Journal 47, 30-38, December 2005. Accessed July 30, 2014:

http://bookstore.ashrae.biz/journal/download.php?file=282741stiburek.pdf.

Metzger, C.E.; Wilson, E.; Horowitz, S. (2012). Addendum to the Building America House Simulation Protocols. Golden, CO: National Renewable Energy Laboratory. DOE/GO-1020123855. Accessed December 26, 2013: http://www.nrel.gov/docs/fy13osti/57450.pdf.

Otis, C.; Maxwell, S. (2012). Measure Guideline: Air Sealing Attics in Multifamily Buildings. Consortium for Advanced Residential Buildings. DOE/GO-102012-3573. Accessed April 22, 2014: http://www.carb-swa.com/Collateral/Documents/CARB-SWA/Guides/Air Sealing_Attics Multifamily.pdf. 


\section{Appendix: 2012 IECC Multifamily Air Sealing Guide}




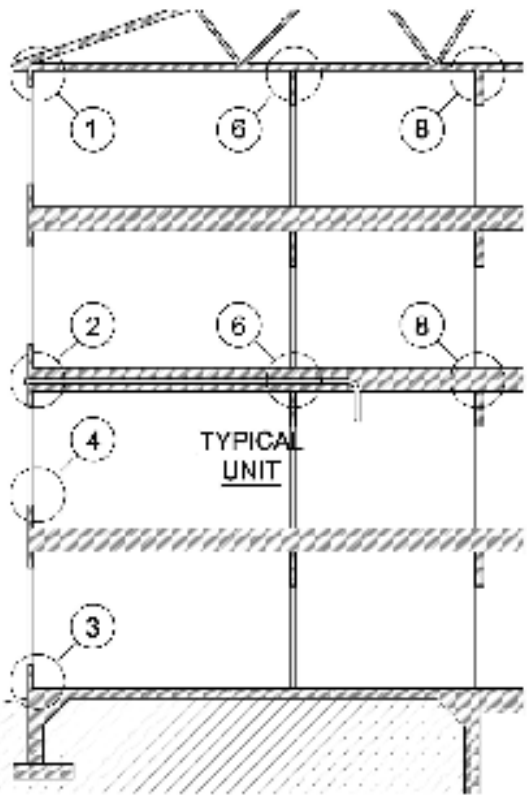

SECTION KEY

TYPICAL MULTIFAMILY BUILDING

\section{ELEVATION KEY}

TYPICAL WOOD-FRAMED BUILDING

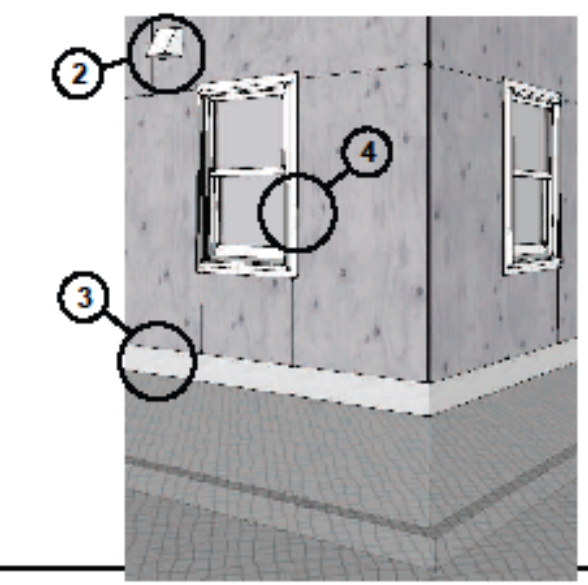

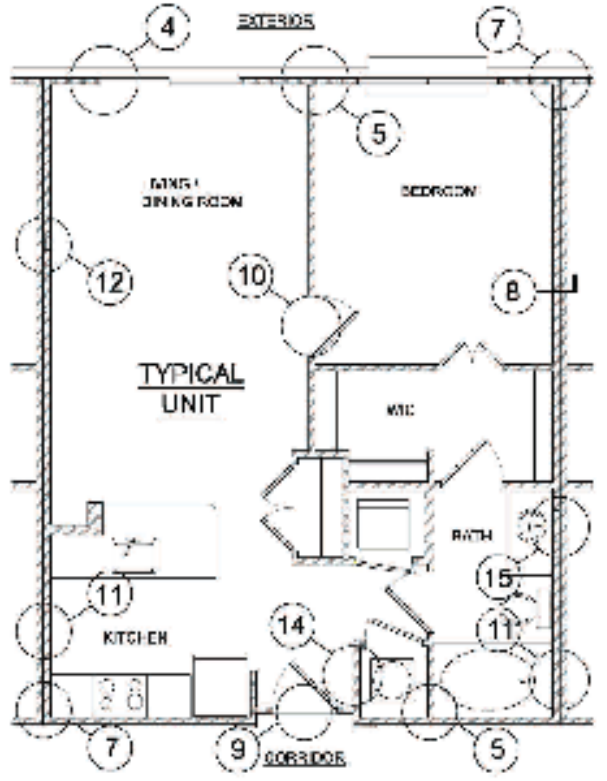

PLAN KEY

TYPICAL UNIT PLAN

\section{RULES OF THUMB}

1. Design simple layouts (minimal comers, etc.)

2. Install wood framing with tight connections and minimize extra material

3. Do not use resilient channels on exterior walls or apartment-side of interior walls

4. Use temperature-appropriate sealant (i.e. high -temp caulk at flues, heating pipes, etc.)

5. Clean out cracks before applying sealant (i.e. compressed air, vacuum, damp cloth, etc.)

6. Assign responsibility to one trade/person for confirming completion of air sealing tasks (this guide includes suggestions for which trades should be initially responsible for each task) 


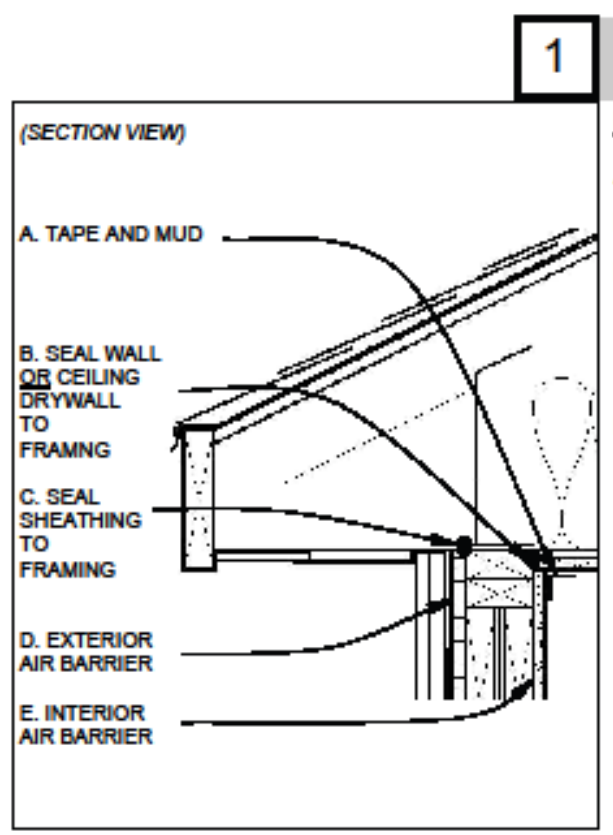

\section{EXTERIOR WALL - TOP}

\section{Notes:}

A. Typical

B, C. Elastomeric sealant

D. Options:

- Sheathing with seams sealed (i.e. ply wood or rigid foam board)

- Fluid-applied/adhesive membrane on

sheathing (i.e. Grace / Henry products)

E. Drywall: typical

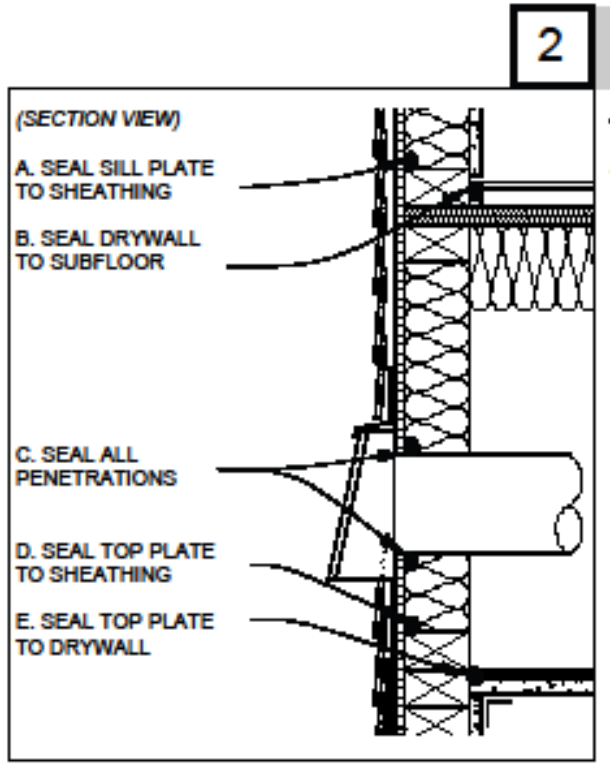

\section{EXTERIOR WALL - MIDDLE}

Notes:

A, C, D, E. Elastomeric sealant

B. Self-leveling subfloor (i.e. gypcrete)

C. Includes ducts, pipes, wires, etc. (high priority) 

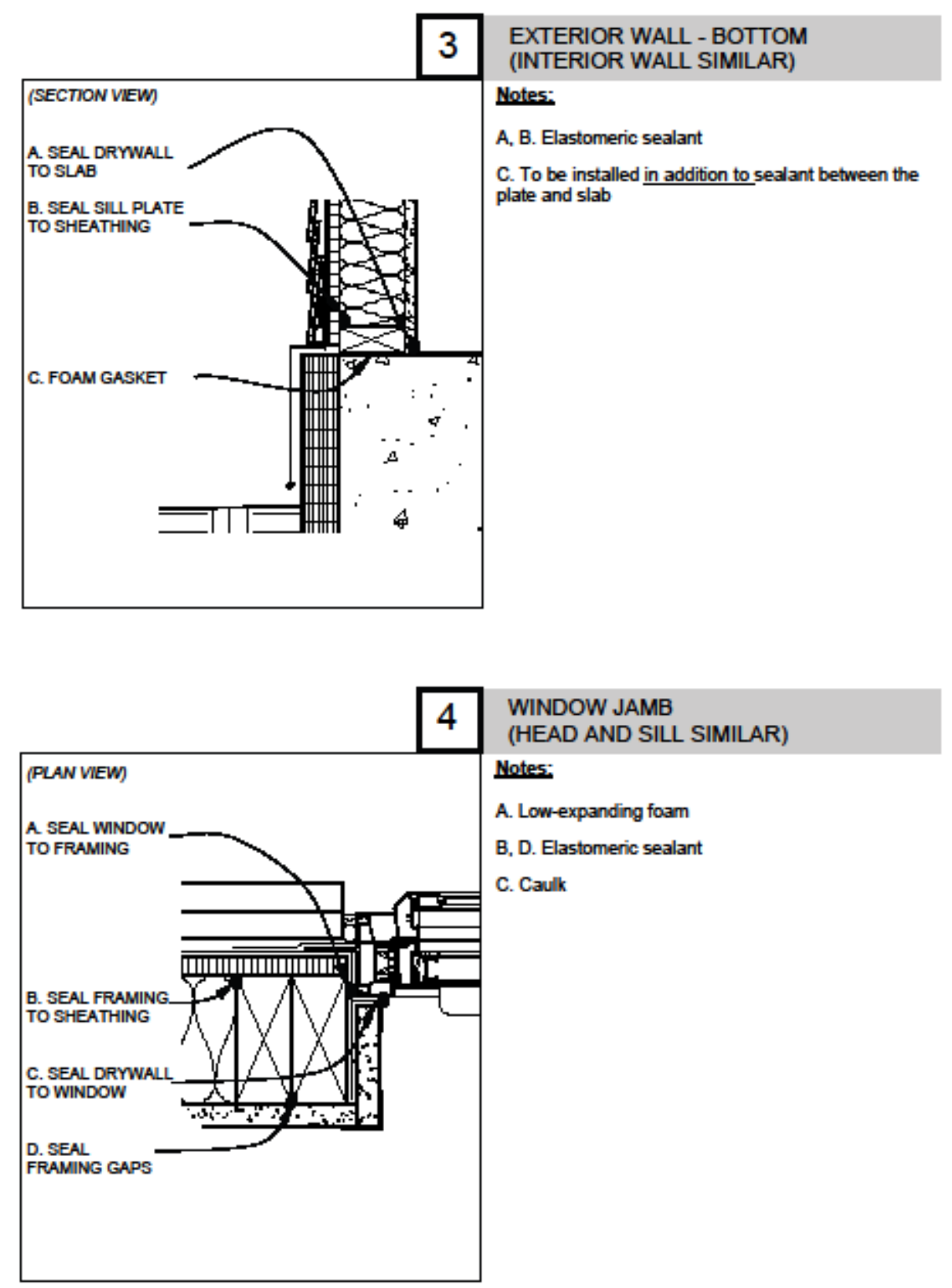

WINDOW JAMB

(HEAD AND SILL SIMILAR)

Notes:

A. Low-expanding foam

B, D. Elastomeric sealant

C. Caulk

Steven Winter Assoclates, Inc. 


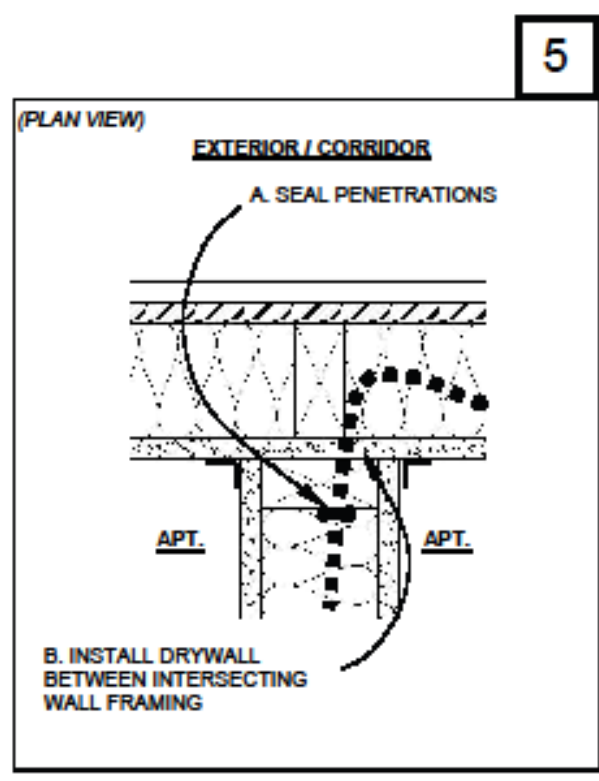

INTERIOR PARTITION AT EXTERIOR/ CORRIDOR WALL

\section{Notes:}

A. Fire caulk (penetrations include ducts, pipes, wires, etc.).

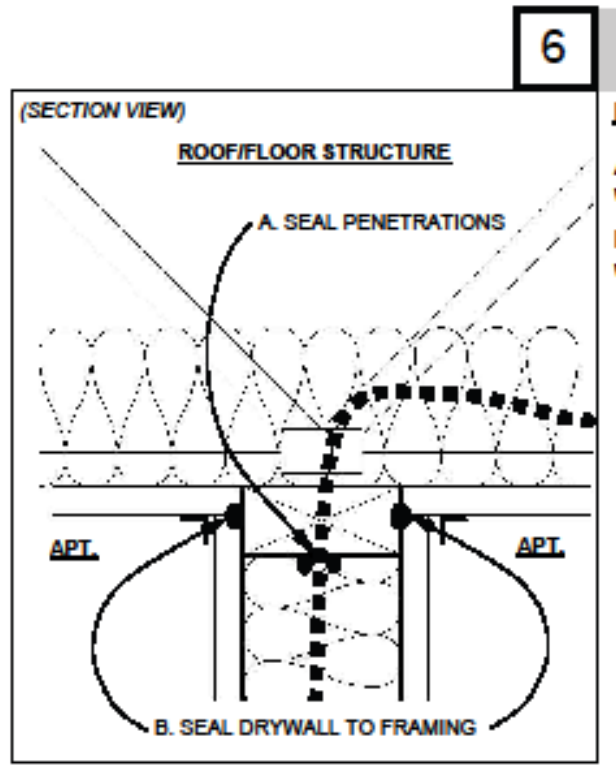

INTERIOR PARTITION - TOP

Notes:

A. Fire caulk (penetrations include ducts, pipes, wires, etc.).

B. Elastomeric sealant (before interior partition drywall is installed) 


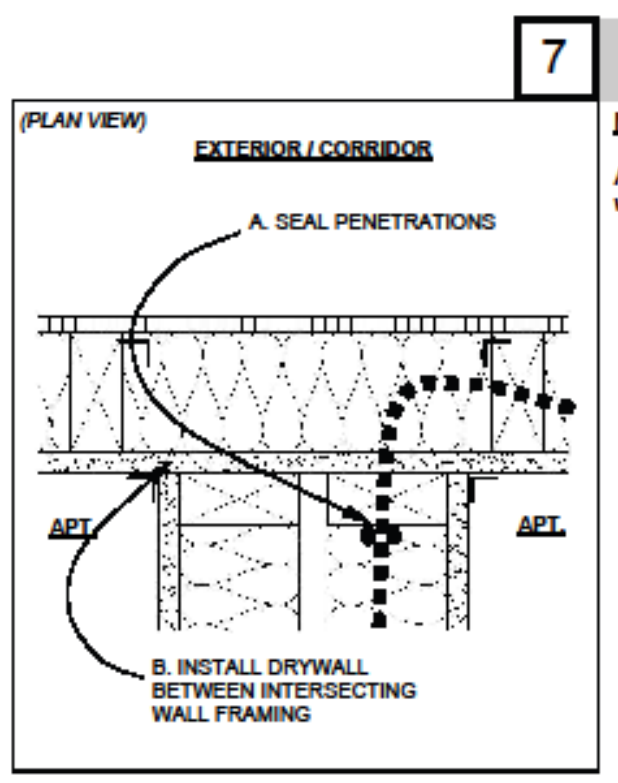

DOUBLE-FRAMED DEMISING WALL AT EXTERIOR/CORRIDOR WALL

\section{Notes:}

A. Fire caulk (penetrations include ducts, pipes, wires, etc.).

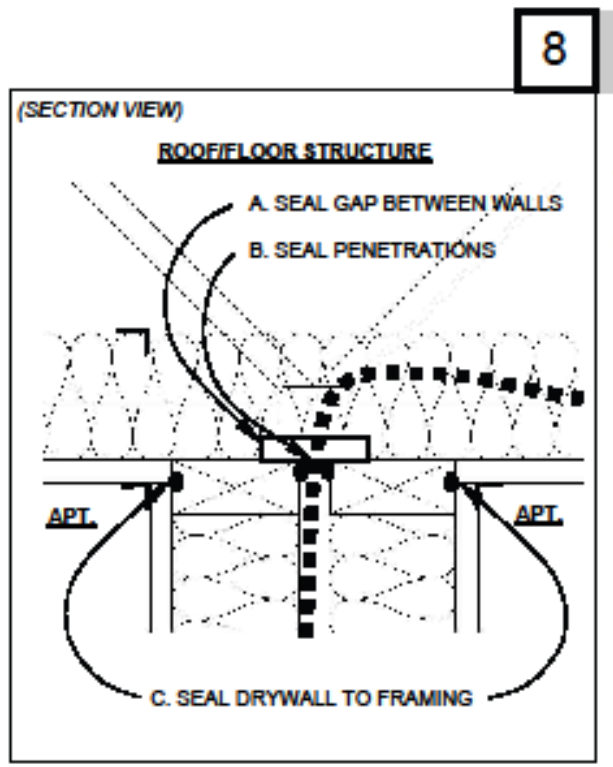

DOUBLE-FRAMED DEMISING WALL TOP (SHAFTS SIMILAR)

\section{Notes:}

A. Solid blocking and elastomeric sealant

B. Fire caulk (penetrations include ducts, pipes, wires, etc.)

C. Elastomeric sealant (before demising wall drywall is installed) 

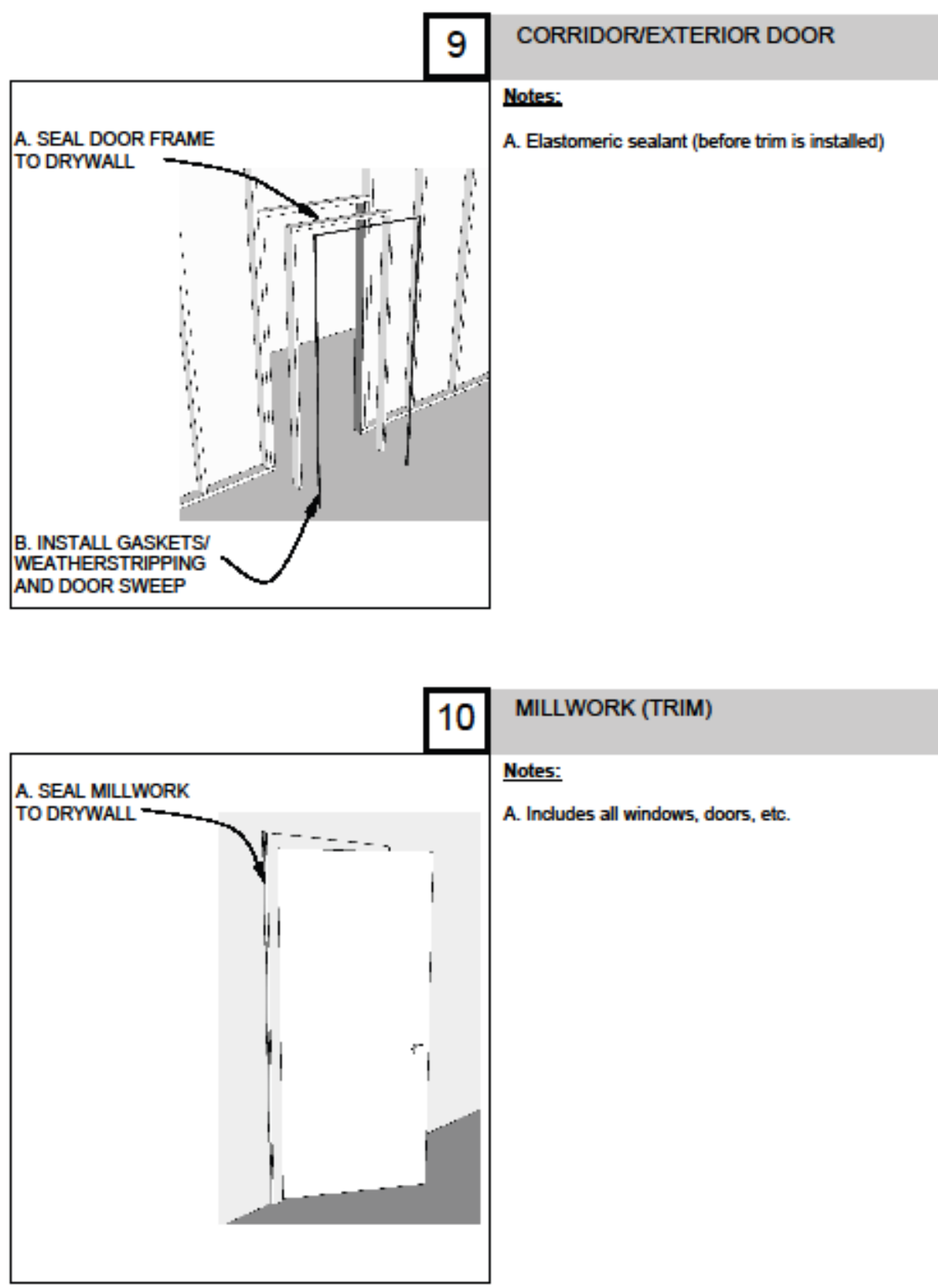

MILLWORK (TRIM)

Notes:

A. Includes all windows, doors, etc.

Steven Winter Assoclates, Inc. 


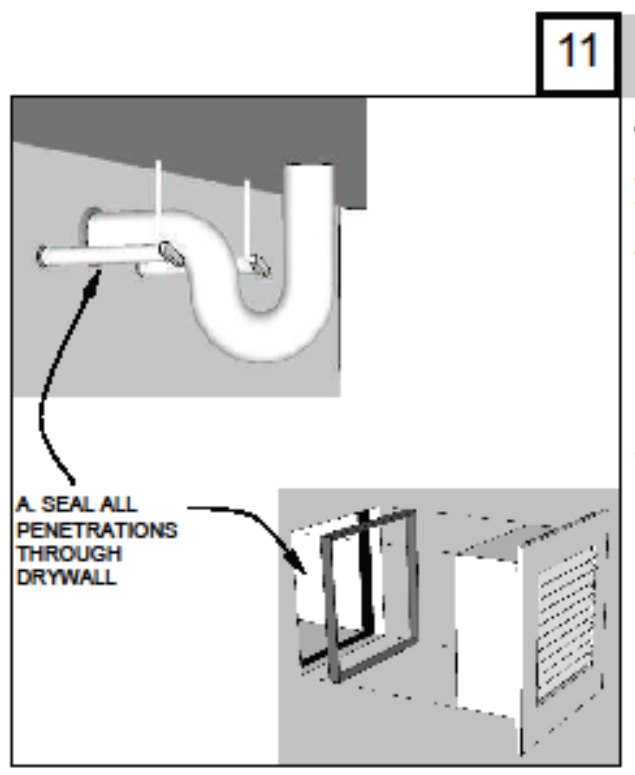

\section{PLUMBING PENETRATIONS}

\section{Notes:}

A. Seal all penetrations BEFORE installing cabinetry and/or escutcheons

A. Typical plumbing penetrations include:

- Sink faucet supplies \& drain

- Toilet supply

- Showerhead stub-out

- Heating supplyireturn

- Gas supply

- Sprinklers

"'NOT REQUIRED AT INTERIOR PARTITIONS"'

12

\section{ELECTRICAL BOXES}

Notes:

A, B, C. Includes boxes in floors and ceilings

A, C. Mastic is preferable to caulk or foam

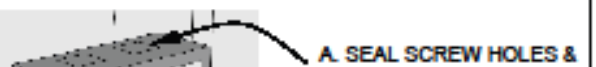

"'NOT REQUIRED AT INTERIOR PARTITIONS"'

B. SEAL BOX

TO DRYWALL

C. SEAL WIRE

PENETRATIONS 


\section{3}

A. SEAL RECESSED LIGHT HOUSING TO DRYWALL

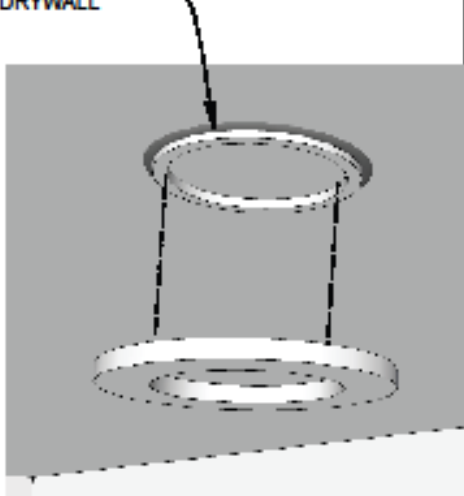

14

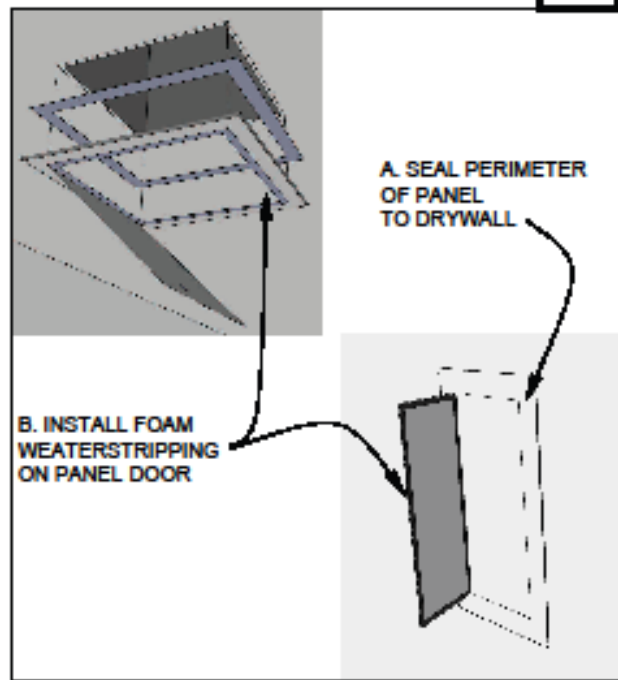

\section{RECESSED LIGHTING}

\section{Notes:}

A. Use insulation contact air-tight cans (ICAT)

\section{UTILITYIACCESS PANELS}

Notes:

A. Caulk

B. Inexpensive, adhesive-backed weatherstripping usually works best

-'INSTALL UTILITYIACCESS PANELS IN INTERIOR PARTITIONS ONLY-DO NOT INSTALL IN WALLCEILING ASSEMBLIES SHARED WITH ADJACENT APARTMENTS OR COMMON AREAS ${ }^{\text {mI }}$ 


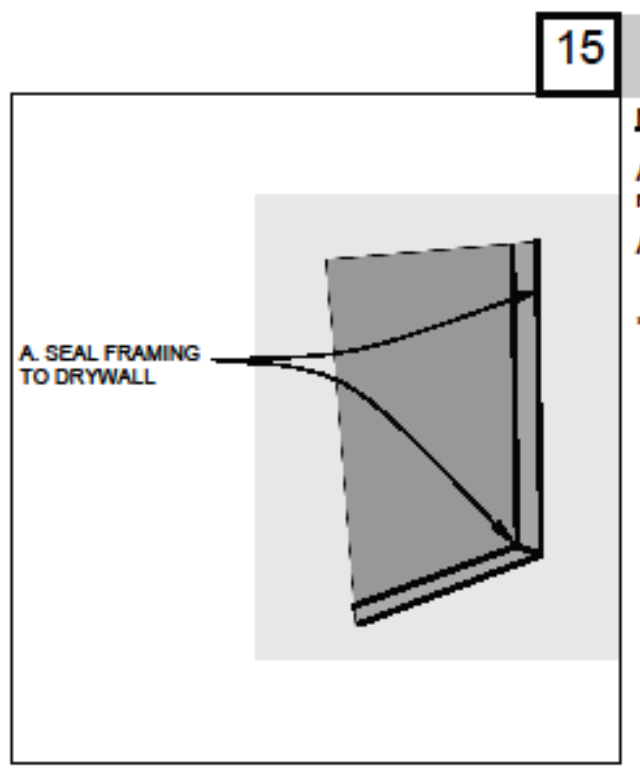

RECESSED COMPONENTS

\section{Notes:}

A. Seal all cracks/seams BEFORE recessed component is installed

A. Typical recessed components include: - Medicine cabinet

"'NOT REQUIRED AT INTERIOR PARTITIONS"'

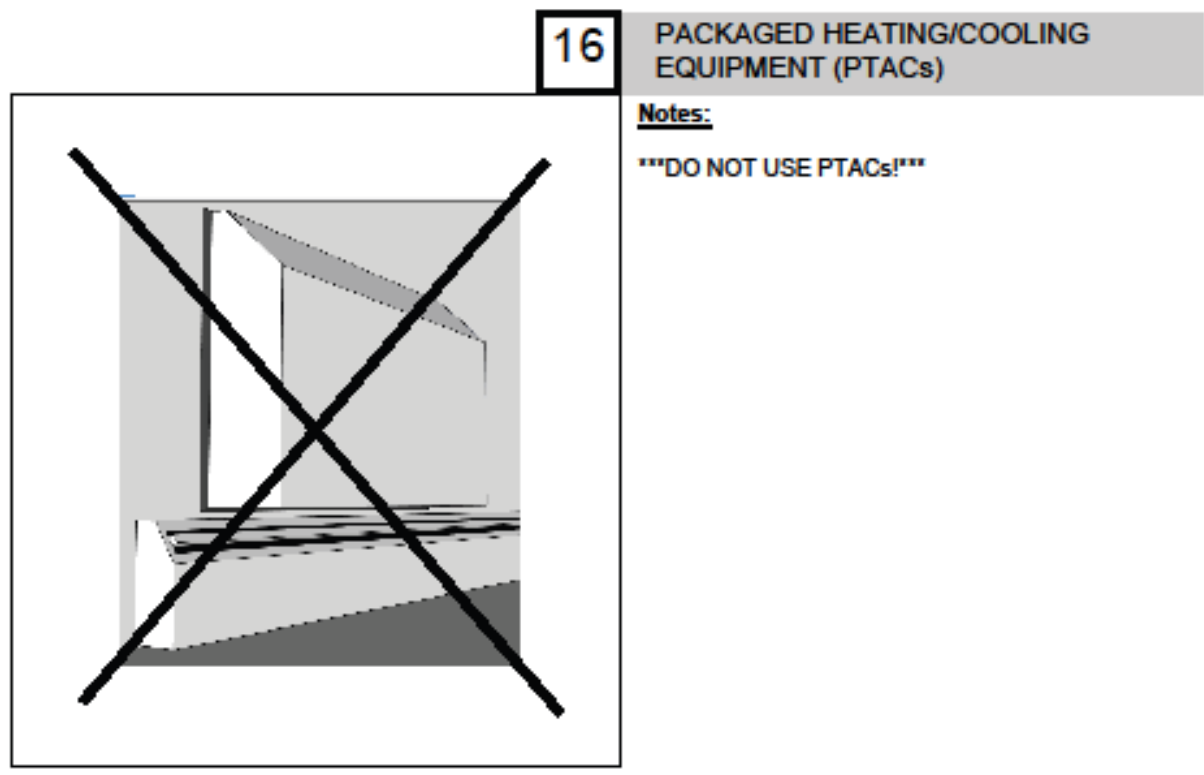

Steven Winter Assoclates, Inc. 
